\title{
The effect of natural radioactivity on diatom communities in mineral springs
}

\author{
Fanny Millan $^{\mathrm{a}, \mathrm{b}}$, Cheilla Izere ${ }^{\mathrm{c}}$, Vincent Breton ${ }^{\mathrm{c}, \mathrm{b}}$, Olivier Voldoire ${ }^{\mathrm{a}}$, David G. Biron ${ }^{\mathrm{d}, \mathrm{b}}$, \\ Carlos E. Wetzel ${ }^{\mathrm{e}}$, Didier Miallierc, Elisabeth Allain ${ }^{\mathrm{a}}$, Luc Ector ${ }^{\mathrm{e}}$ and Aude Beauger ${ }^{\mathrm{a}, \mathrm{b}}$
}

aUniversité Clermont Auvergne, CNRS, GEOLAB, F-63000 Clermont-Ferrand, France;

bLTSER “Zone Atelier Territoires Uranifères”, F-63000 Clermont-Ferrand, 63178 Aubière Cedex, France ; 'Université Clermont Auvergne, CNRS/IN2P3, Laboratoire de Physique de Clermont, UMR6533, 4 avenue Blaise Pascal TSA 60026, CS 60026, 63178 Aubière cedex, France; ${ }^{\mathrm{d}}$ CNRS UMR 6023, Université Clermont-Auvergne, Laboratoire "Microorganismes: Génome et Environnement" (LMGE), 63178 Aubière Cedex, France; ${ }^{e}$ Department Environmental Research and Innovation (ERIN), Luxembourg Institute of Science and Technology (LIST), Belvaux, Luxembourg

CONTACT Aude Beauger aude.beauger@uca.fr Université Clermont Auvergne, CNRS, GEOLAB, F-63000 Clermont-Ferrand, France

\begin{abstract}
Diatoms are good indicators of water quality because of their great diversity and wide ecological range. They are also interesting in assessing the impact of radioactivity on ecosystems because of their capacity to absorb radioelements. They also show radio-induced deformities, observed in many species. In order to assess more precisely the impact of natural radioactivity, diatom communities were monitored during a 9-month survey in two mineral springs characterized by radioactivity levels ranging within two orders of magnitude. The experimental data obtained were analyzed using different multivariate and clustering analyses. The richness was high with the dominance of Planothidium frequentissimum and Crenotia angustior. In the most radioactive spring known in Auvergne (above $4000 \mathrm{~Bq} \mathrm{~L}{ }^{-1}$ radon activity), the average deformation was $24.7 \%$, in contrast with lower teratological rates observed in the less radioactive spring. In the absence of heavy metals, this result confirmed that radioactivity is an environmental stress for the diatoms living in these particular ecosystems. This conclusion was reinforced by the selection of springs from a database of 126 ecosystems comparable to our studied sites except the lower level of radioactivity. In these "mirror" springs, few deformations were observed.
\end{abstract}

\section{KEYWORDS}

Natural radioactivity; mineral springs; diatoms; teratological forms; biocenosis 


\section{Introduction}

Diatoms are widely used to assess water quality. However, few studies have been conducted on the impact of ionizing radiations and radionuclides on these organisms (e.g. Rose 1992; Snoeijs and Notter 1993; Shcherbak 1999a, b; Wasser, Stupina, and Starenko 1999). Diatoms have advantages over adsorption and absorption because of their high surface-to-volume ratio. Moreover, the diatom frustule is surrounded by a thin organic envelope associated with complex cations such as iron and aluminum, useful in reducing the loss of silica by dissolution (Round, Crawford, and Mann 1990). As a consequence, radionuclides are likely to be attached to the organic layer around the frustules. Thus, diatoms could be used as monitoring organisms when radionuclide releases are low and therefore are below the detection limit for macroalgae and higher trophic levels (Snoeijs and Notter 1993). In addition, they: 1) are essential in the food chain, 2) are present in many environments, and 3) potentially accumulate radionuclides proportionally to releases into the environment while not selecting the type of radionuclide.

Shuryak's (2018) study on species richness and abundance of plankton in radioactive waterbodies confirmed that effects can be observed at low or moderate levels of radioactive contamination on individual health, reproduction or genomic integrity of diatoms. Concerning species richness and abundance, they would be, according to other studies, not intensely affected (Polikarpov 1998; Murphy, Nagorskaya, and Smith 2011; Beresford et al. 2013; Webster et al. 2016). In contrast, according to Herlory et al. (2013), diatom community (on artificial substrates) was modified by heavy metal rich mine waters affecting environmental conditions (uranium and chemical contamination at well-water treatment plants).

Shcherbak (1999a) investigated the impact of radioactive contamination on the structural and functional characteristics of algal communities of the Dnieper River in the Chernobyl exclusion zone. Low doses of radiation did not inhibit the growth and production of algae, and natural successions associated with biological effects caused by the influence of weak irradiation layers accelerated the processes specific to the functioning of algal communities. Snoeijs and Notter (1993) studied the role of benthic diatoms as radionuclide monitoring organisms in brackish coastal environments in the vicinity of a nuclear power plant (Northern Baltic Sea). They showed that the distance from the discharge point and hydrographical conditions determined the level of radionuclides in the diatom community. After the Chernobyl accident, Snoeijs and Notter (1993) also report very high radionuclide concentrations found in diatom samples, especially at sites with little water exchange.

Exposure to various environmental stressors is abundantly documented to modify the diatom frustules. In unstressed populations, it is rare to find teratological forms, so that a $1 \%$ rate of abnormal forms already seems significant (Straub and Jeannin 2006). Teratological forms generally have a distorted contour of the valve and/or a different size, but considerable changes in the shape, number, and configuration of the striae and areolae may also appear (Ross and Mann 1986). Some submicroscopic features may also change, and all these changes may potentially alter cell movement and physiological mechanisms. Several studies report a significant positive correlation between the abundance of individuals with teratological forms and environmental constraints such as: 1) temperature and drought, inducing abnormal silica deposits (Antoine and Benson-Evans 1986); 2) UV-light affecting biochemistry and cellular morphology (Hessen, De Lange, and Van Donk 1997; Falasco et al. 2009a); 3) mechanical damage (grazing or clutter in the biofilm); 4) salinity by affecting structures by osmotic pressure (abnormalities of valves and ornamentation, Stoermer and Andresen 2006); 5) nutrient-rich conditions causing changes in some species; 6) nutrient depletion that appears to induce the production of sickle-shaped, beaked and lobed cells with ripple margins (Håkansson and 
Korhola 1998); 7) the presence of heavy metals in the water column and sediments (PeresWeerts 2000, Morin et al. 2012).

Although radionuclide accumulation is expected to impact diatom metabolism and genome, no publication has documented so far the correlation between radioactivity and diatom frustule deformities.

In this paper we explore for the first time the potential role of natural radioactivity as an environmental stressor on diatom communities. For this purpose, a 9-month survey of diatom communities living in naturally radioactive mineral springs located in an ILTER (International Long Term Ecological Research network) research site, the Zone Atelier Territoires Uranifères (https://zatu.org/) located in the Auvergne region (France) was conducted. Mineral springs are considered as isolated ecosystems (Werum 2001; Whittaker, Willis, and Field 2001) with specific biocenosis due to their discontinuous presence in the landscape (Cantonati et al. 2012). Thus, focusing on Auvergne mineral springs allow us to have a controlled environment as these habitats often offered a high stability of physical and chemical parameters (van der Kamp 1995). For this study, the main aim was to explore the relationships between natural radioactivity and the biodiversity of diatoms assessing the community structure. Different statistical analyses were conducted to discriminate the influence of the physical and chemical variables of the different springs, including radioactivity. Moreover, special attention was paid to the rate of teratological forms (i.e. identification of the type of deformations; correlation with the radon concentration). To reinforce our results, the diatom communities of the studied springs were compared to those living in "mirror springs" (i.e. springs characterized by comparable water chemistry, but significantly lower levels of radioactivity) by using a clustering analysis.

\section{Materials and methods}

\section{Study sites}

The volcanic history of the Massif Central lead to the emergence of many mineral springs. Indeed, the internal activity of this region associated with carbon dioxide emissions allows the groundwater to rise to the surface via the faults in the rocks. During their flow through these faults, the waters increase their concentrations in chemical elements. Two springs were chosen for the present study following previous measurements performed in the sediments surrounding their borders and showing high ${ }^{226} \mathrm{Ra}$ activity, respectively 31.4 and $31.9 \mathrm{kBq} \mathrm{kg}^{-1}$ (Vincent Breton, personal communication). The springs, called "La Montagne" and "Mariol", are located $4.5 \mathrm{~km}$ from each other in the Montagne Bourbonnaise area at altitudes of 368.7 and 308.5 meters, respectively (Figure 1).

The mineral spring called La Montagne, is located near the city of Châteldon (E 741086.699, $\mathrm{N}$ 6542796.817). This spring has been known for a long time to be naturally radioactive, with a radon activity documented around $105 \mathrm{nCi} \mathrm{L}{ }^{-1}$ (3885 Bq L-1) (Jacquet 1929). The spring is located $3.75 \mathrm{~km}$ away from a former uranium mine (Guiollard 2002), which confirms the presence of uranium veins around this area. This spring was divided in two study sites: La Montagne 1, which is located under a small building linked to the former bottling history, and La Montagne 2, which is on the other side of the road, a few meters away. La Montagne 1 site has stagnant water and, by its configuration, is sensitive to the flow and effects of precipitation, while La Montagne 2 presents running waters. These two sites are connected by an underground route via a concrete pipe. La Montagne 2 is certainly the result of a mix of several overflows 
from different springs, as well as runoff and precipitation. Indeed, the concrete pipe is not directly related to the emergence of the spring "La Montagne". A few kilometers from Châteldon, the second studied spring is located near the city of Mariol (E 739134.341, N 6546926.368) and emerges in a bowl placed $50 \mathrm{~cm}$ above the ground. As a consequence, it is not affected by water runoff, and precipitation does not dilute its water due to its permanently filled basin.

\section{Diatom sampling and physico-chemical analyses}

Sampling campaigns were carried out between May 2018 and March 2019, except in June and November 2018. The geographical position of the sampling site was taken using a DGPS Trimble Geo7x, in Lambert 93. Each month, dissolved oxygen (\% and $\left.\mathrm{mg} \mathrm{L}^{-1}\right)$, conductivity $\left(\mu \mathrm{S} . \mathrm{cm}^{-1}\right)$ and temperature $\left({ }^{\circ} \mathrm{C}\right)$ were measured in situ using an Ysi ProODO oxygen probe and a multi-parameter WTW FC probe 340i. Ambient gamma-ray dosimetry (expressed in microSieverts per hour $\left(\mu S v h^{-1}\right)$ ) was also measured in situ using a Colibri radiometer (Mirion Technology). In situ, two water samples were collected from each site for further physical and chemical analysis, one using a previously rinsed bottle to measure ionic concentrations and another using a Marinelli beaker for gamma spectrometry. In the French Massif Central, spring water radioactivity is largely coming from gaseous dissolved radon $\left({ }^{222} \mathrm{Rn}\right)$ and its short-lived daughters, most notably ${ }^{214} \mathrm{~Pb}$ and ${ }^{214} \mathrm{Bi}$ (Boineau and Maisonneuve 1972). The springs also contain mineral radioelements such as ${ }^{226} \mathrm{Ra},{ }^{228} \mathrm{Ra}$ and ${ }^{40} \mathrm{~K}$. They are either dissolved or aggregated as particles, depending on water physico-chemical properties. Most often, the overall water radioactivity can be approximated to the activity of radon $222\left({ }^{222} \mathrm{Rn}\right)$ and its daughters. The radon activity was measured by gamma-spectrometry at LPC using a germanium detector (Courtine et al. 2008). Since ${ }^{222} \mathrm{Rn}(\mathrm{T}=3.85 \mathrm{~d})$ is not a $\gamma$-emitting nuclide, its activity is routinely evaluated on the basis of the activity of its short-lived, $\gamma$-emitting daughter, ${ }^{214} \mathrm{~Pb}(\mathrm{~T}=26.8 \mathrm{mn})$. Also, because radon activity keeps decreasing once water has been sampled, correction factors have to be introduced in order to finally quote the results in $\mathrm{Bq} \mathrm{L}^{-1}$ at sampling time (i.e. at the spring).

The measure of radon activity was repeated for each sampling site during the survey period: May 2018, January 2019 and April 2019 for La Montagne 1, January and April 2019 for La Montagne 2 and, May 2018 and April 2019 for Mariol spring.

In addition to radioactivity, water $\mathrm{pH}$ was measured using a multi-parameter WTW FC 340i probe as well as carbonate concentration $\left(\mathrm{HCO}_{3}{ }^{-}\right)$using a Hach carbonate kit. Cation and anion contents (lithium $\left(\mathrm{Li}^{+}\right)$, sodium $\left(\mathrm{Na}^{+}\right)$, ammonium $\left(\mathrm{NH}_{4}^{+}\right)$, potassium $\left(\mathrm{K}^{+}\right)$, magnesium $\left(\mathrm{Mg}^{2+}\right)$, calcium $\left(\mathrm{Ca}^{2+}\right)$, fluorine $\left(\mathrm{F}^{-}\right)$, chlorides $\left(\mathrm{Cl}^{-}\right)$, nitrites $\left(\mathrm{NO}_{2}{ }^{-}\right)$, nitrates $\left(\mathrm{NO}_{3}{ }^{-}\right)$, phosphates $\left(\mathrm{PO}_{4}{ }^{3-}\right.$ ) and sulphates $\left(\mathrm{SO}_{4}{ }^{2-}\right)$ were measured using high pressure ion chromatography devices (Thermo Scientific Dionex ICS1100 and Thermo Scientific Dionex DX120). In addition, an analysis of trace elements was carried out using ICP Mass Spectrometry device at Laboratoire Magma et Volcans (LMV, CNRS-UCA) on a water sample collected in January 2019 at La Montagne 1.

Diatom sampling was adapted according to the different sites, and then vials were named and dated. For La Montagne 1, the sediments were recovered by scraping directly with the vial, the first millimeters of mud; for La Montagne 2 site, diatoms were taken by brushing the small rocks; and for Mariol, diatoms were sampled on the travertine deposit present at the drop of the spring using a toothbrush. 
A small sub-sample of epipelic raw material was prepared for light microscopy (LM) observation following the method described in Prygiel and Coste (2000). Samples were cleaned using hydrogen peroxide $\left(\mathrm{H}_{2} \mathrm{O}_{2}, 35 \%\right)$ and hydrochloric acid $(\mathrm{HCl})$, and rinsed several times with distilled water. Cleaned material was diluted with distilled water to avoid excessive concentrations of diatom valves on the slides. Then, a drop of dried, clean material was mounted in Naphrax ${ }^{\circledR}$. LM observations and morphometric measurements were done using a Leica ${ }^{\circledR}$ DM2700M microscope with a 100x oil immersion objective using a differential interference contrast. For each slide, 400 valves were counted. Once the counting was complete, the relative abundances of diatom species were calculated.

Teratological forms and normal forms were counted separately. To obtain a robust percentage of teratological individuals, the following protocol was applied. For each slide, 300 different valves were observed and classified into teratological or normal. For this protocol, we retained only individuals in valve view. However, this simple observation under the microscope remains somewhat subjective and depends on the observer (Lavoie et al. 2017). In order to mitigate this source of error as much as possible, teratological rates and the overall counting for each studied mineral spring were performed by only one person.

For the scanning electron microscopy (SEM), parts of the oxidized suspensions were filtered with additional deionized water through a $3 \mu \mathrm{m}$ Isopore polycarbonate membrane filter (Merck Millipore). Filters were mounted on aluminum stubs and coated with platinum using a Modular High Vacuum Coating System BAL-TEC MED 020 (BAL-TEC AG, Balzers, Liechtenstein). An ultrahigh-resolution analytical field emission (FE) scanning electron microscope, Hitachi SU-70 (Hitachi High-Technologies Corporation, Japan) operated at $5 \mathrm{kV}$ and $10 \mathrm{~mm}$ distance, was used for the analysis. SEM images were taken using the lower (SE-L) and upper (SE-U) detector signal and sometimes tilted up to an angle of $28^{\circ}$.

\section{Characterization of teratologies}

Analysis of teratologies focused on the deformation of the valve outline (loss of symmetry relative to both axes; abnormal outline: bent, jagged, incised, etc.) according to Falasco et al. (2009b). As the process is long, we retained some individuals among the 300, presenting different valves outlines. With the photography of the different individuals, the DiaCurv software tool was used to quantify diatom frustule deformations (Wishkerman and Hamilton 2017). In order to determine if a specimen deviates sufficiently from its expected form to be considered abnormal, its morphology is evaluated by positioning markers all around the contours of the valve. From the markers coordinates for each diatom, its deformation is computed. However, abnormalities on deformed ornamentation patterns and on modifications of the raphe are not taken into account.

\section{Data analysis}

All statistical analyses were performed using the free and open source R software 3.4.4 (R Core Team 2014) and the packages FactoMiner (Lê et al. 2008) et Vegan (Oksanen et al. 2013; Oksanen 2015). 
Physical and chemical variables of La Montagne (sites 1 and 2) and Mariol springs were studied using Principal Component Analyses (PCA). Because of their peculiar chemistry, the May 2018 samples were excluded from the analyses. Some variables were selected using a step-wise method before performing non-parametric Kruskal-Wallis tests in order to study their monthly variations. The null hypothesis of this test is the homogeneity of the random distribution of the different samples. It is carried out on the variables selected by the Akaike Information Criterion (AIC) selection method and the Bayesian Information Criterion (BIC), which consists of selecting variables and keeping only those that are statistically significant from our model (database). The selection of variables also makes it possible for us to remove redundant and coevolving variables together, strengthening the robustness of tests that follow. Moreover, a Multiple Factor Analysis was used to explain the distribution of individuals (in our case the sites La Montagne 1, La Montagne 2 and Mariol) by variables structured in groups. The chemical compositions of our database have been classified into four main groups including the group of pollutants $\left(\mathrm{Cl}^{-}, \mathrm{NH}_{4}{ }^{+}, \mathrm{NO}_{2}{ }^{-}, \mathrm{NO}_{3}{ }^{-}, \mathrm{PO}_{4}{ }^{3-}, \mathrm{SO}_{4}{ }^{2-}\right.$ ), deep rise indicators $\left(\mathrm{Li}^{2+}, \mathrm{F}^{-}\right)$, other major ions giving information on the geological nature of the rock encountered by water $\left(\mathrm{Na}^{+}\right.$, $\mathrm{K}^{+}, \mathrm{Mg}^{2+}, \mathrm{Ca}^{2+}, \mathrm{HCO}_{3}{ }^{-}$) and finally the group of "Physical variables" (conductivity, water temperature, $\mathrm{pH}$ and dissolved $\mathrm{O}_{2}$ ). The carbonate concentration and the conductivity were added as supplementary variables.

\section{Diatoms data statistical analyses}

To study the dispersion of diatom species on La Montagne 1, La Montagne 2 and Mariol sites, Factorial Correspondence Analysis (FCA) was used on species with relative abundance higher than $1 \%$. To reinforce the FCA, an Adonis test was performed to explain the distribution of species in relation to the physical and chemical variables (selected using a step-wise method). Using the coordinates obtained for each diatom with DiaCurv, an R script allowed to realize a PCA on the dataset and to obtain a graph showing the extreme forms of the valves observed for each spring (Wishkerman and Hamilton 2017). Moreover, a PCA was conducted on the three sites to compare the evolution and correlation of the following variables: percentage of teratological valves, nitrate concentration and radon activity. Whenever the radon activity measurement was missing, its average value over the survey period was used.

\section{Comparison with “mirror” springs}

In order to confirm the role of natural radioactivity in the observed patterns, "mirror" mineral springs presenting the same physical and chemical properties, but significantly lower radioactivity level, were selected in a database developed by GEOLAB (A. Beauger). Among the 126 mineral springs documented in the database, a PCA analysis allowed us to select the mineral springs displaying the closest physical and chemical compositions to La Montagne and Mariol springs. The PCA analysis was supported by two classification analysis methods, the Ascending Hierarchical Clustering (AHC) and the classification by the mobile centre method (k-means), where individuals (springs) are classified according to their characteristics (physical and chemical variables). The same protocol was used to evaluate the rate of teratological forms in La Montagne, Mariol and their mirror springs. Ambient Gamma dosimetry and radon activity 
in "mirror" spring water were also measured using the same devices and techniques in May 2019.

\section{Results}

Physical and chemical characteristics of La Montagne and Mariol sites

An overall PCA of all the data collected during the 9-month survey showed that the samples collected in May 2018 on the two sites of La Montagne (La Montagne 1, La Montagne 2) spring displayed a very specific pattern, specifically a high nitrate concentration. Indeed, samples were collected just after a heavy rain which resulted in a mixture of the run-off and mineral spring waters. The Mariol spring (from July to January) had a higher fluorine level and water content than La Montagne spring (sites 1, 2) (Figure 2). La Montagne spring (sites 1, 2) had a higher concentration of lithium, other major ions $\left(\mathrm{Ca}^{2+}, \mathrm{Na}^{+}, \mathrm{HCO}_{3}{ }^{-}, \mathrm{Mg}^{2+}, \mathrm{K}^{+}\right)$and conductivity. It can also be noted that the concentrations of $\mathrm{NH}_{4}{ }^{+}, \mathrm{SO}_{4}{ }^{2-}, \mathrm{Cl}^{-}, \mathrm{NO}_{3}{ }^{-}$and $\mathrm{PO}_{4}{ }^{3-}$ were higher on $\mathrm{La}$ Montagne spring (sites 1, 2) than on Mariol spring. Moreover, the two sites of La Montagne spring were differentiated by higher concentrations in $\mathrm{NO}_{3}{ }^{-}, \mathrm{Cl}^{-}, \mathrm{PO}_{4}{ }^{3-}$ and, dissolved oxygen in La Montagne 2 site than in La Montagne 1 site (Tables 1-3).

To identify the spatial and temporal differences, the step-wise method lead to retain: $\mathrm{Li}^{+}, \mathrm{NO}_{3}{ }^{-}$ , $\mathrm{F}^{-}, \mathrm{K}^{+}, \mathrm{Mg}^{2+}, \mathrm{Cl}^{-}, \mathrm{NH}_{4}{ }^{+}$and $\mathrm{Ca}^{2+}$. Then, a Kruskal-Wallis test was performed on these selected variables: 1) Mariol differed from La Montagne 1 in its $\mathrm{Li}^{+}$(p-value: 0.001) and $\mathrm{K}^{+}$(p-value: 0.001) concentrations; 2) Mariol differed from La Montagne 2 in its nitrate concentration (pvalue: 0.002); 3) the differentiation of Mariol with La Montagne (sites 1, 2) lies in its concentrations in $\mathrm{F}^{-}$(p-value: 0.03 La Montagne 1; p-value: $<0.0001$ La Montagne 2), $\mathrm{Ca}^{2+}$ (pvalue: $<0.0001$ La Montagne 1; p-value: 0.001 La Montagne 2) and $\mathrm{Mg}^{2+}$ (p-value: $<0.0001 \mathrm{La}$ Montagne 1; p-value: 0.005 La Montagne 2); 4) $\mathrm{NH}_{4}{ }^{+}$was the only variable that showed significant monthly variations for the three sites ( $p$-value $=0.023$ ).

The multiple factor analysis showed the distribution of springs by groups of physical and chemical variables (Figure 3). La Montagne 1 is characterized in March by a high quantity of pollutants, especially $\mathrm{NO}_{3}{ }^{-}$(Figure 3). Lastly, the Mariol spring is associated with the group of "physical variables" (Figure 3; Tables 1-3).

Table 4 provides a summary of the radon activity in $\mathrm{Bq} \mathrm{L}^{-1}$ measured during the 9-month survey at Mariol and La Montagne. Radon concentrations measured at Mariol spring are very stable while measurements at La Montagne display significant variations that were not expected and will require further analysis. In a first step, whenever radon measurements were not available, we used as a reasonable guess the average activity measured during the survey period.

\section{Diatom assemblages}

The specific richness was 65 for La Montagne 1, 51 for La Montagne 2 and 73 for Mariol. Planothidium frequentissimum (Lange-Bertalot) Lange-Bertalot was the dominant species at La Montagne 1 and Mariol (mean: 45\% and 69\% respectively) and Crenotia angustior (Grunow) Wojtal dominated at La Montagne 2 (mean: 44\%). A Factorial Component Analysis (not presented) showed that Sellaphora labernardierei Beauger, C.E.Wetzel \& Ector in 
Beauger et al. (2016) (SLAB) dominated in Mariol spring, in May and July 2018. Many individuals of Nitzschia amphibia Grunow were observed at La Montagne 1 and La Montagne 2 sites in August 2018 and at La Montagne 1 site in March 2019. Another FCA was carried out after removing the samples collected in May and July 2018 at Mariol site (Figure 4). On this second FCA, a dominance of Planothidium frequentissimum teratological (abnormal) form appeared in May 2018 on La Montagne 1. Otherwise, most of the identified species showed no spring and seasonal preference.

Based on the results of the Adonis test, the selected physical and chemical variables obtained using the step-wise method $\left(\mathrm{Li}^{+}, \mathrm{NO}_{3}{ }^{-}, \mathrm{F}^{-}, \mathrm{K}^{+}, \mathrm{Mg}^{2+}, \mathrm{Cl}^{-}, \mathrm{PO}_{4}{ }^{3-}, \mathrm{pH}\right.$ and oxygen) do not influence the distribution of species communities between the three sites (p-value $>0.05$ ).

\section{Teratological characterization of the diatom communities}

Deformations were observed on frustule valve outline as well as changes in striation pattern. Focusing on the percentage of teratological forms, a difference was observed in the rate of deformed valves between La Montagne (sites 1 and 2) and Mariol springs (Figure 5). La Montagne 1 had an average of 24.34\% deformed valves compared to 25.98\% for La Montagne 2 and $6.58 \%$ for the Mariol spring.

To further characterize the deformities, the larger sample of individuals of Planothidium frequentissimum was focused upon, as this species dominated the community at La Montagne 1 and Mariol sites. The plate used for this analysis consisted of 72 valves of Planothidium frequentissimum from both springs (La Montagne and Mariol), collected between August 2018 and March 2019. For the PCA done using the coordinates of the valve outline, four extreme forms were represented on the first factorial plan (Figure 6). The right-hand form was represented by a large number of individuals from spring Mariol while the left-hand form is a mix of individuals from Mariol and La Montagne. The last two forms at the top and bottom of the first factorial plan, are more representative of individuals observed at La Montagne spring. As with DiaCurv software, only valve outline was examined, SEM observations were done. Deformations were observed on valve outline, cavum-bearing and raphe for different species, mainly on Humidophila perpusilla (Grunow) R.L.Lowe, Kociolek, J.R.Johansen, Van de Vijver, Lange-Bertalot \& Kopalová, Planothidium frequentissimum and Crenotia angustior (Figure 7).

At last, the PCA conducted on the three sites to compare the rate of deformed valves with nitrate concentration and radon activity underlined that radon concentration and teratogenicity are highly correlated and move in the same direction (Figure 8). The correlation coefficient obtained between radon activity and the rate of teratological valves is about 0.65 with a p-value $=3.65 \mathrm{e}-0.5$, confirming our assumption of high correlation. On the other hand, there was a low correlation between the nitrate concentration and the teratogenic rate. The Chi-square test had a correlation coefficient of 0.39 and a p-value equal to 0.046 . 
PCAs allowed to identify eight springs geochemically close to La Montagne 1 and Mariol springs: Sainte Marie, Fontaine Goyon, Val d’Enfer, Fontaine salée, Font salée (Apchon), Teyssière (font Salada), Puits2 and Henri springs (Figure 9). The Henri, Sainte-Marie, Fontaine Goyon and Font salée (Apchon) springs are characterized by a high concentration of $\mathrm{Mg}^{2+}, \mathrm{Cl}^{-}$ and $\mathrm{SO}_{4}{ }^{2-}$, while Teyssières (font Salada) and Puits2 are characterized by higher, $\mathrm{K}^{+}, \mathrm{Ca}^{2+}$ and $\mathrm{PO}_{4}{ }^{3-}$ concentrations (Figure 9).

The distribution of the eight "mirror" springs with the La Montagne 1 and Mariol springs obtained by the two classification methods (the Hierarchical Ascending Clustering (HAC) and the classification by the mobile centre method (k-means), underlined a similarity of these springs in physical and chemical composition. Two groups were distinguished (Figure 10): 1) the springs of Fontaine Goyon, Val d'Enfer, Fontaine salée and Mariol (July, August, September, October, December, January, February and March) form the second group characterized by low average of ion concentrations such as $\mathrm{Mg}^{2+}, \mathrm{K}^{+}, \mathrm{Cl}^{-}, \mathrm{Na}^{+}$) and a high average concentration of $\mathrm{F}^{-}$and low conductivity (Table 5); 2) Henri, Sainte Marie, Teyssières (font Salada), Font salée (Apchon), Puits2 and La Montagne 1 (July, August, September, October, December, January, March) springs form the first group characterized by a high average concentration of $\mathrm{HCO}_{3}{ }^{-}, \mathrm{Ca}^{2+}, \mathrm{Li}^{+}, \mathrm{K}^{+}, \mathrm{Cl}^{-}, \mathrm{Na}^{+}$, and high conductivity.

Radon activity of some of these "mirror" springs could not be measured as they were inaccessible: 1) due to its hydrology for Henri spring located near the Allier River; 2) the presence of snow that prevented sampling Val d'Enfer spring; 3) new layout (grid presence) preventing sampling of Puits spring. For the others, radon activities in water are displayed on Table 6.

For the springs selected as "mirror" springs, the percentage of teratological forms was obtained. It varied between 3.1 and $10.5 \%$ (Table 7). The dominant and also the most affected genus was Planothidium whatever the spring.

\section{Discussion}

\section{Physical and chemical variables}

One of the special features of mineral spring waters in the Vichy Saint-Yorre basin, including Châteldon, is their high fluorine concentrations (from 2 to $3 \mathrm{mg} \mathrm{L}^{-1}$ ), a marker of their deep origin (Bertin and Rouzaire 2004). When comparing the two springs studied, Mariol displayed the highest concentration in fluorine (2 to $3 \mathrm{mg} \mathrm{L}^{-1}$ according to Risler 1974). During our survey, this concentration was about $5 \mathrm{mg} \mathrm{L}^{-1}$. Moreover, the lithium, also indicative of deep water origin (Michard 1990), was found in significant concentration at La Montagne spring (0.76 mg L $^{-1}$ ). At last, the conductivity was lower at the spring of Mariol. This mineralization is dependent on the path taken by the groundwater before surfacing, and is therefore dependent on the rocks crossed (Risler 1974). Thus, Mariol differed statistically from La Montagne 1 and La Montagne 2 sites by its lower concentrations of lithium, potassium, nitrates, calcium and magnesium and its higher fluorine concentration.

Comparing the two sites at La Montagne spring, the La Montagne 2 site was more oxygenated, probably in relation to its running waters, while La Montagne 1 presents stagnant water. La Montagne 2 site also contained higher concentration of phosphates, nitrates and chlorides, three 
components indicative of potential pollution. Due to the mineral nature of the studied springs, chlorides will not be retained as an indicator of pollution. Nitrates and phosphates could come from agricultural activities present on the watershed, from nitrogen fertilizers and waste water discharges (water containing manure or decomposing organic matter). Moreover, as the La Montagne 2 site could be a mix of several springs associated with runoff water (Magaud, personal communication), it can be assumed that several overflow waters are mixed with rainwater at this location. Physical and chemical ion concentration can therefore be impacted.

Beyond the original characteristics of different springs, precipitation is often the cause of changes in the physical and chemical parameters. Indeed, dilutions due to these precipitations can reduce the concentrations of some parameters. In the case of La Montagne spring, rain can lead to runoff and leaching, thus potentially supplying chemicals from farms (e.g. nitrogen or phosphorus). Reciprocally, during the drought period an increase in the concentrations of some elements could have occurred. It was the case in a particularly dry period from July 2018 to

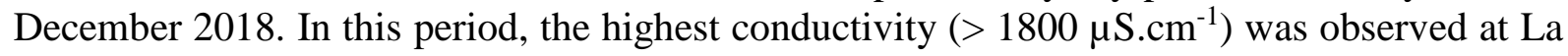
Montagne 1 site.

This double impact of precipitation could explain La Montagne 1 data collected in March 2019 as concentrations of sodium, lithium, magnesium, calcium, carbonates, fluorine and conductivity have decreased, probably due to this phenomenon of dilution. However, chloride and nitrate levels have significantly increased, probably as a result of runoff inputs (Figure 2). At La Montagne 2 site an increase of the nitrates or the phosphorus concentrations were observed, but in a less significant way. It would seem that during low rainfall, La Montagne 2 site was less impacted than La Montagne 1 site. During larger rainfall, significant changes in the physical and chemical parameters of the two sites of La Montagne spring could have occurred as in May 2018. Indeed, the nitrate concentration of the two sites was the highest, reaching $11 \mathrm{mg} \mathrm{L}^{-1}$. It is possible that this is due to the configuration of La Montagne 1 site, placed under a concrete building, more easily flooded and diluted and able to store potential pollutants.

Regarding ammonium, a higher concentration was observed at La Montagne 1 site, which is probably due to its stagnant character in the former building and filtration basins and/or due to the presence of dead leaves and animals in water. In addition, rain and snow contain traces of ammonium, so precipitation can potentially be responsible for this type of variation (Rodier, Legube, and Merlet 2009). It is therefore probable that ammonium variation is due to these two phenomena. This change was statistically significant as the Kruskal-Wallis tests carried out revealed temporal variation for this variable and, with the PCA, a higher concentration of ammonium was associated to the La Montagne 1 site. The Mariol spring, because of its configuration, is less likely to be affected. Indeed, the catchment emerges into a basin about 50 $\mathrm{cm}$ high, which allows it to avoid the risk of runoff. Moreover, the basin being continuously filled, the risks of dilutions are also less present.

Radon activity in water is more than one order of magnitude higher in La Montagne spring compared to Mariol (Table 4). Previous measurements performed in the sediments on the borders of the two springs had shown similar ${ }^{226} \mathrm{Ra}$ activity, respectively 31.4 and $31.9 \mathrm{kBq} \mathrm{kg}^{-}$ ${ }^{1}$. Assessing precisely the radiation dose received by diatoms living in these springs will require a very detailed analysis of the spatial distribution of the different radioelements. If we consider only radon and its daughters, the average radiation dose received by diatoms in La Montagne spring is about $1 \mathrm{mSv}$ per hour. For a sake of comparison, the average annual radiation dose to a person from radon is about $2 \mathrm{mSv}$ per year. 
To further assess if the teratological forms observed at La Montagne spring could be caused by the presence of other environmental stress factors, an analysis of the trace elements in the water sample collected on January $18^{\text {th }} 2019$ was performed using ICP Mass Spectrometry. Most of the trace elements were below the limit of detection (Co, Cu, Zn, Ge, Se, Mo, Ag, Cd, In, Sn, Sb, REE, HFSE (Zr, Nb, Hf, Ta), W, Re, Tl, Te, Bi, Th) while the highest measured concentrations were those of lithium and strontium followed by barium and rubidium (Table 8). The concentrations of lead and arsenic were low (0.052 and $0.064 \mathrm{mg} \mathrm{L}^{-1}$ respectively). However, the concentration of these elements, not necessary to the metabolism, could influence the diatom and induce toxicity even at very low concentrations (Morin 2006). On the other hand, "non-essential" metals can sometimes increase the algal biomass and metabolic processes (Falasco et al. 2009a). The concentration of lead was higher than $3.2 \mu \mathrm{g} \mathrm{L}{ }^{-1}$, which is the limit for a chronic exposure in freshwater systems (Aquatic Life Criteria, US EPA 2014) and could therefore modify the communities. According to $\mathrm{Mu}$ et al. (2018), lead could induce significant changes in chlorophyll $a$ content depending on the species studied. Moreover, greatly widened cell deformation occurs after lead exposure at concentration $>0.1 \mathrm{mg} \mathrm{L}^{-1}$ which is greater than La Montagne 1 site concentration $\left(0.052 \mathrm{mg} \mathrm{L}^{-1}\right)$. At last, for Peres and Coste (2006), a concentration of $1.5 \mathrm{mg} \mathrm{kg}^{-1}$ induce only $3.5 \%$ of abnormalities. Conversely, the concentration of arsenic was far below $150 \mu \mathrm{g} \mathrm{L}^{-1}$ (Aquatic Life Criteria, US EPA 2014). However, Barral-Fraga et al. (2018) underlined that there is accumulation of arsenic in the sediment and that it can be easily transferred from sediments to other compartments such as biota, and consequently, be more available. For Peres and Coste (2006), a concentration of 1.5 mg kg-1 As induce only $1.8 \%$ of abnormalities.

In summary, the springs revealed differences between them, however, they are still stable physico-chemically since the characters do not change over the months (except for ammonium and radioactivity). The presence of radon was high in La Montagne spring compared to Mariol spring and the presence of heavy metal was low.

\section{Structure of the diatom assemblages}

Considering the diatom communities observed at each site, even if the richness was high, the springs were dominated by Planothidum frequentissimum and Crenotia angustior with and without abnormalities. At Mariol, in May and July 2018, Sellaphora labernardierei, a species of mineral springs, was well represented (Beauger et al. 2016). This species is associated with high concentrations of nitrates (Beauger et al. 2016). However, nitrate or other pollutants levels in Mariol on these dates were not high. Conversely, Nitzschia amphibia was significantly present in March 2019 at La Montagne 1 site. It could be due to the high nitrate levels recorded at that date as this species prefers alkaline freshwater with medium to high levels of electrolytes and trophic levels (Lange-Bertalot et al. 2017). Moreover, a high concentration of abnormal forms of Planothidium frequentissimum was observed at La Montagne 1 on May 2018 (Figure 4). It was probably due to heavy rainfall having increased the concentration of nitrates. Even in the face of these features particular to some months, the diatom communities of La Montagne and Mariol springs were similar as underlined by the statistical analyses.

With regard to the teratological forms, the highest percentage of abnormalities occurred at La Montagne spring. At La Montagne 1, the highest radon activity in the water was observed. Moreover, positive correlation occurred between the radon concentration and the percentage of teratological forms. However, it remains impossible to exclude the possibility of additive or synergistic effects of heavy metals or the interaction of other environmental factors in the development of teratology such as the salinity. Indeed, according to some studies, salinity can 
act as a poison, and thus induce teratological forms (Schmid 1980; Håkansson and Chepurnov 1999). Since thermal springs are characterized by their high salinity, it seems important to take into account this factor as cause of teratological forms. However, as the two springs studied had similar sodium concentrations, a low concentration in chloride and different percentage of teratological forms, salinity could not be retained even if it is possible that this factor potentially increased the phenomenon of deformation.

According to Falasco et al. (2009a), stressful environments are dominated by small organisms with faster metabolism and flux rates. Indeed, the sensitivity to stress would be greater in large organisms with longer life spans (Granetti 1968). Thus, it could explain that Planothidium frequentissimum (La Montagne 1 site and Mariol) and Crenotia angustior (La Montagne 2 site), small species, were the most abundant in this stressful environment. In addition, it is possible that some species are potentially more resistant than others to this radioactive stress. Navicula sanctamargaritae Beauger (Beauger et al. 2015), for example, seems to be less affected by this radioactivity. Indeed, despite numerous observations of this species in mineral springs therefore in stressful environments, few deformed valves were observed. It was the case for a sample taken on the sediments of the spring called "Ours" at the city of Joze where the concentration of radium in the sediments was high $\left(30.8 \mathrm{kBq} \mathrm{kg}^{-1}\right)$ and where some abnormalities of the valve shape were observed. It had also been noted that some individuals were smaller than the classical size recognized in the literature (length, width and ratio $\mathrm{L} / \mathrm{w}$ ). This was the case for Planothidium frequentissimum and Crenotia angustior (Millan 2018-2019), but also for Pinnularia sinistra Krammer in a radioactive spring of the Czech Republic where radon activity as high as $7250 \pm 13 \mathrm{~Bq} \mathrm{~L}^{-1}$ was measured (A. Beauger pers. obs. 2018).

With the characterization of teratological forms, a degree in the deformation of valve outline appeared as a loss of symmetry relative to both axes and the outline. Many of the deformed frustules presented "cymbelliclinum-like teratologies (CLT)" (Cantonati et al. 2014). However, the deformations were not only on the valve shape but also on the raphe and at the cavum structure. Some valves of Planothidium frequentissimum did not present a narrow aperture towards the mantle as the type species (Wetzel et al. 2019) (Figure 7). It is important to highlight that the cavum is a stable taxonomic character (Jahn et al. 2017) and its degree of deformation could also be an indicator of the level of contamination, although it is not possible to exclude the fact that the observed teratology and its degree may depend on the stress affecting the valve. In fact, Olenici et al. (2017) demonstrated a deformation gradient of teratological forms of Achnanthidium minutissimum (Kützing) Czarnecki from acid mine drainage. In addition, they found a positive relationship between the degree of deformation of the valve outline and dissolved zinc concentrations. This relationship confirms the hypothesis of Lavoie et al. (2017) and Cantonati et al. (2014) stating that the severity of deformity could provide valuable additional information.

Since the percentages of teratological forms are higher in La Montagne spring, it would seem that the higher the activity of radon in water, the higher the rate of teratological forms. These two parameters are linked. To reinforce our results, a selection of springs with similar physical and chemical composition as La Montagne and Mariol springs, but without radon activity, were retained from a database. Even if the radon activity was not significant, it appeared that some of them sheltered diatoms with teratological forms. Indeed, at Fontaine Goyon and Fontaine Salée springs, the percentage was around $10 \%$. It is possible that these teratological forms appeared because of high manganese concentrations. Indeed, the Fontaine Goyon site has a manganese content of $2255 \mu \mathrm{g} \mathrm{L}^{-1}$ (Gal and Gadalia 2010). Concerning the Fontaine Salée spring, the manganese content was $3120 \mu \mathrm{g} \mathrm{L}^{-1}$ (unpublished GEOLAB analysis). Although 
other springs have low percentages of teratogenic forms, the latter are not less than $1 \%$ (Straub and Jeannin 2006). Indeed, despite the fact that they are not radioactive, mineral springs still remain constraining environments for diatoms.

\section{Conclusion}

The two springs studied, La Montagne and Mariol were characterized by different physical and chemical properties. Mariol spring is less mineralized and has a lesser radon content than La Montagne. However, the diatom communities sheltered by both springs were not significantly different. So the mineralization and radioactivity, in this case, did not induce differences on algal communities. However, teratological forms were observed in each site with a percentage higher than $20 \%$ at La Montagne site. The statistical analyses confirmed a correlation between radon activity and these deformations. Moreover, it appeared, that the radon content of water influenced the rate of teratological forms rather than the presence of radioelements in sediments, since on average there are more teratological forms in La Montagne spring than in Mariol spring. Using "mirror" springs, the radioactivity of the mineral spring of La Montagne significantly influenced the diatoms and induced teratological forms. To reinforce this study, it would be pertinent to do an analysis focusing on a sample group of mineral springs characterized by an increasing gradient of radioactivity.

\section{Acknowledgements}

Funding for this research was partly provided by the Direction Régionale de l'Environnement, de l'Aménagement et du Logement Auvergne-Rhône-Alpes, and by the Zone Atelier Territoires Uranifères. Co-funding was provided by in the framework of the DIATOMS project (LIST - Luxembourg Institute of Science and Technology). We are thankful to PierreJean Gauthier for ICPMS analysis of La Montagne 1 sample and Paul Hamilton for his help to use DiaCurv. We also thank Eduardo A. Morales (Laboratório da Água, Universidade de Évora, Portugal) for his precious comments and corrections and Professor Karen K.

Serieyssol for her English corrections.

\section{Disclosure statement}

No potential conflict of interest was reported by the authors.

\section{Notes on contributors}

Fanny Millan is a student in master's degree at GEOLAB. Contribution: biological analysis of diatom communities, first version of article.

Cheilla Izere is a student in bachelor's degree. Contribution: statistical analyses of spring data, first edition of article chapter on results.

Vincent Breton is Research Director at CNRS. After 11 years of research in hadronic physics (CNRS bronze medal, 1994), he has been studying for 20 years interfaces between physics, life sciences, health and IT. Co-author of more than 150 publications in scientific journals and peer-reviewed conference proceedings (h index: 46). Contribution: ambient gamma dosimetry measurements; water sample collection; discussion of results and development of manuscript.

Olivier Voldoire is engineer assistant at the CNRS. He has participated in more than 20 articles. He is specialized in scientific instrumentation and particularly in physical and 
chemical analyses. He participates in the research program "Biodiversity study of the diatoms of mineral springs of the French Massif Central”. Contribution: participate to the creation of Tables 1, 2, 3 and discussion of the physical and chemical results.

David Biron is CNRS researcher. 24 years of research on "host-parasite interactions and the dynamics of biodiversity" via an integrative biology approach from the cell to the ecosystem. 62 publications in "international peer review journals", 1 ebook (co-editor), 7 book chapters (books); 60 scientific papers in congresses (oral and posters); 48 invited lectures in laboratories and learned societies (h-index: 27). Scholarships obtained for graduates Studies (Master and Thesis, FCAR and CRSNG fellowships) and postgraduate (post-docs, Haigneré and Chateaubriand fellowships). Contribution: discussion of results and development of manuscript.

Carlos E. Wetzel is a botanist and a researcher at the Luxembourg Institute of Science and Technology. He has written over 98 articles and he has been working on diatoms in rivers, lakes and soils. He has been teaching numerous training courses on diatom ecology and taxonomy designed for biologists, technicians and ecologists, contributing to the continuous improvement in the Water Framework Directive implementation in Europe. Contribution: discussion of results and development of manuscript.

Didier Miallier is a University professor at University Clermont-Auvergne. He has written over 60 articles. He is an expert in radiological measurements. Contribution: water radon activity measurements.

Elisabeth Allain is a technician at the CNRS. She has participated in more than 20 articles. She is specialized in sampling treatment and preparation and works on diatoms. She participates in the research program "Biodiversity study of the diatoms of mineral springs of the French Massif Central”. Contribution: participate to the part materials and methods.

Luc Ector is a botanist and senior researcher at the Luxembourg Institute of Science and Technology. He has written over 200 articles and has been working on diatoms in rivers, lakes and soils for the last 30 years. He was the President of the "Association des Diatomistes de Langue Française (ADLaF)", which organizes annual meetings on diatom taxonomy, ecology and related subjects. Over the last 20 years, he has been organizing and teaching numerous training courses on diatom ecology and taxonomy designed for biologists, technicians and ecologists, contributing to the continuous improvement in the Water Framework Directive implementation in Europe. Contribution: provision of literature, discussion of results and development of manuscript.

Aude Beauger is an ecologist and $\mathrm{PhD}$ at the Centre National de la Recherche Scientifique. She has written over 30 articles and she has been working on diatoms in rivers, lakes and springs. She has been teaching on bioassessment using diatoms. She is the treasurer of the "Association des Diatomistes de Langue Française (ADLaF)" and has organized the annual meeting on diatom taxonomy, ecology and related subjects in 2014. Contribution: create the research program "Biodiversity study of the diatoms of mineral springs of the French Massif Central”, participate to the writing of the results, discussion and development of manuscript.

\section{ORCID}


Aude Beauger https://orcid.org/0000-0002-0911-0500

Vincent Breton https://orcid.org/0000-0001-8197-7080

Carlos E. Wetzel https://orcid.org/0000-0001-5330-0494

David Biron https://orcid.org/0000-0002-1182-5951

Luc Ector https://orcid.org/0000-0002-4573-9445

\section{References}

Antoine, S. E., and K. Benson-Evans, 1986. “Teratological variations in the River Wye diatom flora, Wales, U.K.” In Proceedings of the Eighth International Diatom Symposium. Paris, August 27 - September 1, 1984, edited by M. Ricard, 375-384. Koenigstein: Koeltz Scientific Books.

Barral-Fraga, L., D. Martiñá-Prieto, M. T. Barral, S. Morin, and H. Guasch. 2018. "Mutual interaction between arsenic and biofilm in a mining impacted river." Science of the Total Environment 636: 985-998. doi:10.1016/j.scitotenv.2018.04.287.

Beauger, A., O. Voldoire, A. Mertens, R. Le Cohu, and B. Van de Vijver. 2015. "Two new Navicula species (Bacillariophyceae) from Western Europe.” Phytotaxa 230 (2): 172-182. doi:10.11646/phytotaxa.230.2.4.

Beauger, A., C. E. Wetzel, O. Voldoire, A. Garreau, and L. Ector. 2016. “Sellaphora labernardierei (Sellaphoraceae, Bacillariophyta), a new epilithic species from French spring and four new combinations within the genus Sellaphora.” Phytotaxa 260 (3): 235-246. doi:10.11646/phytotaxa.260.3.3.

Beresford, A. E., G. W. Eshiamwata, P. F. Donald, A. Balmford, B. Bertzky, A. B. Brink, L. D. C. Fishpool, P. Mayaux, B. Phalan, D. Simonetti, and G. M. Buchanan. 2013. "Protection reduces loss of natural land-cover at sites of conservation importance across Africa.” PLoS ONE 8: e65370. doi:10.1371/journal.pone.0065370.

Bertin, C., and D. Rouzaire. 2004. “Amélioration de la connaissance des ressources en eau souterraine des sites thermaux en Auvergne - site du bassin de Vichy (03).” [Improvement of the knowledge of the groundwater resources of the thermal sites in Auvergne - Vichy basin 
site (03)]. Report of B.R.G.M. RP-53095-FR. Orléans: Bureau de Recherches Géologiques et Minières.

Boineau R., and J. Maisonneuve. 1972. “Les sources minérales du Massif Central français et leur cadre géologique.” [The mineral springs of the French Massif Central and their geological setting.] Rapport BRGM 72-SGN-151-MCE.

Cantonati, M., N. Angeli, L. Virtanen, A. Z. Wojtal, J. Gabrieli, E. Falasco, I. Lavoie, S. Morin, A. Marchetto, C. Fortin, and S. Smirnova. 2014. Achnanthidium minutissimum (Bacillariophyta) valve deformities as indicators of metal enrichment in diverse widelydistributed freshwater habitats. Science of the Total Environment 475: 201-215. doi:10.1016/j.scitotenv.2013.10.018.

Cantonati, M., L. Füreder, R. Gerecke, I. Jüttner, and E. J. Cox. 2012. “Crenic habitats, hotspots for freshwater biodiversity conservation: toward an understanding of their ecology.” Freshwater Science 31 (2): 463-480. doi:10.1899/11-111.1.

Courtine F., T. Pilleyre, S. Sanzelle, and D. Miallier. 2008. “Ge well detector calibration by means of a trial and error procedure using the dead layers as a unique parameter in a Monte Carlo simulation.” Nuclear Instruments and Methods in Physics Research Section A: Accelerators, Spectrometers, Detectors and Associated Equipment 596 (2): 229-234. doi:10.1016/j.nima.2008.07.155.

Falasco, E., F. Bona, G. Badino, L. Hoffman, and L. Ector. 2009a. “Diatom teratological forms and environmental alterations: a review”. Hydrobiologia 623 (1): 1-35. doi:10.1007/s10750-008-9687-3.

Falasco, E., F. Bona, M. Ginepro, D. Hlúbiková, L. Hoffmann, and L. Ector. 2009b. "Morphological abnormalities of diatom silica walls in relation to heavy metal contamination and artificial growth conditions.” Water SA 35 (5): 595-606. doi:10.4314/wsa.v35i5.49185. 
Gal, F., and A. Gadalia. 2010. "Métrologie des fluides de la zone Pavin MontchalMontcineyre.” [Fluid metrology of the Pavin Montchal-Montcineyre area]. Report of B.R.G.M. RP-58129-FR.

Granetti, B. 1968. “Alcune forme teratologiche comparse in colture di Navicula minima Grun. e Navicula seminulum Grun.” [Some teratological forms appeared in cultures of Navicula minima Grun. and Navicula seminulum Grun.]. Giornale Botanico Italiano 102 (6): 469-484. doi:10.1080/11263506809426483.

Guiollard, P.-C. 2002. L'uranium du Morvan et du Forez. Saint-Pourçain-sur-Sioule (Allier): Editions Pierre-Christian Guiollard. 95 p.

Håkansson, H., and V. Chepurnov. 1999. "A study of variation in valve morphology of the diatom Cyclotella meneghiniana in monoclonal cultures effect of auxospore formation and different salinity conditions.” Diatom Research 14 (2): 251-272. doi:10.1080/0269249X.1999.9705469.

Håkansson, H., and A. Korhola. 1998. "Phenotypic plasticity in the diatom Cyclotella meneghiniana or a new species?” Nova Hedwigia 66 (1-2): 187-196.

Herlory, O., J.-M. Bonzom, R. Gilbin, S. Frelon, S. Fayolle, F. Delmas, and M. Coste. 2013. "Use of diatom assemblages as biomonitor of the impact of treated uranium mining effluent discharge on a stream: case study of the Ritord watershed (Center-West France).” Ecotoxicology 22: 1186-1199. doi:10.1007/s10646-013-1106-5.

Hessen, D. O., H. J. De Lange, and E. Van Donk. 1997. "UVinduced changes in phytoplankton cells and its effects on grazers.” Freshwater Biology 38 (3): 513-524. doi:10.1046/j.1365-2427.1997.00223.x.

Jacquet, C. 1928. “Contribution à l'étude des eaux minérales et du magnétisme des roches volcaniques du département du Puy-de-Dôme.” [Contribution to the study of mineral waters and magnetism of volcanic rocks in the department of Puy-de-Dôme]. Paris: Les Presses universitaires de France. 
Jahn, R., N. Abarca, B. Gemeinholzer, D. Mora, O. Skibbe, M. Kulikovskiy, E. Gusev, W.-H. Kusber, and J. Zimmermann. 2017. Planothidium lanceolatum and Planothidium frequentissimum reinvestigated with molecular methods and morphology: four new species and the taxonomic importance of the sinus and cavum. Diatom Research 32 (1): 75-107. doi:10.1080/0269249X.2017.1312548.

Lange-Bertalot, H., G. Hofmann, M. Werum, and M. Cantonati. 2017. Freshwater Benthic Diatoms of Central Europe: Over 800 Common Species Used in Ecological Assessment. English edition with updated taxonomy and added species. Koeltz Botanical Books, Schmitten-Oberreifenberg, Germany.

Lavoie, I., P. B. Hamilton, S. Morin, S. K. Tiam, M. Kahlert, S. Gonçalves, E. Falasco, C. Fortin, B. Gontero, D. Heudre, M. Kojadinovic-Sirinelli, K. Manoylov, L. K. Pandey, and J. C. Taylor. 2017. "Diatom teratologies as biomarkers of contamination: Are all deformities ecologically meaningful?” Ecological Indicators 82: 539-550. doi:10.1016/j.ecolind.2017.06.048.

Lê, S., J. Josse, and F. Husson, F. 2008. FactoMineR: An R Package for Multivariate Analysis. Journal of Statistical Software 25(1): 1-18.

Michard, G. 1990. "Behaviour of major elements and some trace elements (Li, Rb, Cs, Sr, Fe, Mn, W, F) in deep hot waters from granitic areas.” Chemical Geology 89 (1-2): 117-134. doi:10.1016/0009-2541(90)90062-C.

Millan, F. 2018-2019. “Etude des communautés diatomiques de sources minérales naturellement radioactives sur les sites de Châteldon et Mariol dans le Massif Central (63).” [Study of diatom communities living in naturally radioactive mineral springs at the Châteldon and Mariol sites in the Massif Central (63).] Rapport de stage 2ème année de Master. Master Gestion de l'Environnement. Université Clermont-Auvergne. 39 p.

Morin, S. 2006. "Bioindication des effets des pollutions métalliques sur les communautés de diatomées benthiques. Approches in situ et expérimentales.” [Bioindication of the effects of metal pollution on benthic diatom communities. In situ and experimental approaches]. $\mathrm{PhD}$ diss., Université Sciences et Technologies, Bordeaux I. 
Morin, S., A. Cordonier, I. Lavoie, A. Arini, S. Blanco, T. T. Duong, E. Tornés, B. Bonet, N. Corcoll, L. Faggiano, M. Laviale, F. Pérès, E. Becares, M. Coste, A. Feurtet-Mazel, C. Fortin, H. Guasch, and S. Sabater. 2012. "Consistency in diatom response to metal-contaminated environments.” In Emerging and Priority Pollutants in Rivers, edited by H. Guasch, A. Ginebreda, and A. Geiszinger, Handbook of Environmental Chemistry 19: 117-146. Berlin Heidelberg: Springer-Verlag. doi:10.1007/978-3-642-25722-3_5.

Mu, W., Y. Chen, Y. Liu, X. Pan, and Y. Fan. 2018. “Toxicological effects of cadmium and lead on two freshwater diatoms.” Environmental Toxicology and Pharmacology 59: 152-162. doi:10.1016/j.etap.2018.03.013.

Murphy, J. F., L. L. Nagorskaya, and J. T. Smith. 2011. “Abundance and diversity of aquatic macroinvertebrate communities in lakes exposed to Chernobyl-derived ionising radiation." Journal of Environmental Radioactivity 102 (7): 688-694. doi:10.1016/j.jenvrad.2011.04.007.

Oksanen, J. 2015. Multivariate Analysis of Ecological Communities in R: Vegan Tutorial. http://cc.oulu.fi/ jarioksa/opetus/metodi/vegantutor.pdf

Oksanen, J., F. G. Blanchet, R. Kindt, P. Legendre, P. R. Minchin, R. O’Hara, G.L. Simpson, P. Solymos, M. H. H. Stevens, E. Szoecs, and H. Wagner. 2013. Package 'Vegan'. Community Ecology Package, Version 2. http://CRAN.R-project.org/package=vegan.

Olenici, A., S. Blanco, M. Borrego-Ramos, L. Momeu, and C. Baciu. 2017. "Exploring the effects of acid mine drainage on diatom teratology using geometric morphometry.” Ecotoxicology 26 (8): 1018-1030. doi:10.1007/s10646-017-1830-3.

Peres, F., and M. Coste. 2006. “Effets des pollutions métalliques sur les diatomées par l'étude des formes tératologiques au niveau de rivières du bassin Artois-Picardie”. [Effects of metal pollution on diatoms by the study of teratological forms in rivers of the Artois-Picardy basin]. Diatomania 10: 48-61.

Peres-Weerts, F., 2000. Mise en évidence des effets toxiques des métaux lourds sur les diatomées par l'étude des formes tératogènes. Douai: Agence de l’Eau Artois-Picardie. 24 p. 
Polikarpov, G. G. 1998. “Biological aspect of radioecology: objective and perspective.” In Comparative Evaluation of Environmental Toxicants, Proceedings of the International Workshop on Comparative Evaluation of Health Effects of Environmental Toxicants Derived from Advances Technologies, Chiba, January 28-30, 1998, edited by J. Inaba and Y. Nakamura, 3-15. Chiba (Japan): National Institute on Radiology Sciences.

Prygiel, J., and M. Coste. 2000. Guide méthodologique pour la mise en œuvre de l’indice Biologique Diatomées NF T 90-354. Etude Agences de l'Eau-Cemagref Bordeaux, mars 2000. Douai : Agences de l’Eau, 134 pp. + clés de détermination (90 planches couleurs) + cdrom bilingue français-anglais (Tax’IBD).

R Core Team. 2014. R: A language and environment for statistical computing. R Foundation for Statistical Computing, Vienna, Austria. URL http://www.R-project.org/.

Risler, J. J. 1974. Description et classification géologique des sources minérales et thermales du Massif Central [Description and geological classification of the mineral and thermal springs of the Massif Central]. Report of B.R.G.M. 74-SGN-418 MCE. Orléans: Bureau de Recherches Géologiques et Minières, Service des eaux minérales et thermales.

Rodier, J., B. Legube, and N. Merlet. 2009. L’Analyse de l’Eau. 9ème édition. Paris: Dunod. 1579 p.

Rose, K. S. B. 1992. “Lower limits of radiosensitivity in organisms, excluding man.” Journal of Environmental Radioactivity 15 (2): 113-133. doi:10.1016/0265-931X(91)90047-J.

Ross, R., and D. G. Mann. 1986. "What is a diatom species? Report on a workshop.” In Proceedings of the Eighth International Diatom Symposium. Paris, August 27- September 1, 1984, edited by M. Ricard, 743-744. Koenigstein: Koeltz Scientific Books.

Round, F. E., R. M. Crawford, and D. G. Mann. 1990. The Diatoms: Biology and Morphology of the Genera. Cambridge: Cambridge University Press. 
Schmid, A. M., 1980. "Valve morphogenesis in diatoms: a pattern-related filamentous system in pennates and the effect of APM, colchicine and osmotic pressure.” Nova Hedwigia 33: 811-847.

Shcherbak, V. I. 1999a. "Structural and functional characteristics of phytoplankton in the water bodies within the exclusion zone of the Chernobyl Nuclear Power Station.” Hydrobiological Journal 35 (5): 158-174. doi:10.1615/HydrobJ.v35.i5.190.

Shcherbak, V. I. 1999b. "The role of phytoplankton in migration of radionuclides in water bodies differing in the level of radioactive contamination.” Hydrobiological Journal 35 (6): 84-102. doi:10.1615/HydrobJ.v35.i6.80.

Shuryak, I. 2018. "Modeling species richness and abundance of phytoplankton and zooplankton in radioactively contaminated water bodies.” Journal of Environmental Radioactivity 192: 14-25. doi:10.1016/j.jenvrad.2018.05.016.

Snoeijs, P., and M. Notter. 1993. "Benthic diatoms as monitoring organisms for radionuclides in a brackish-water coastal environment.” Journal of Environmental Radioactivity 18 (1): 2352. doi:10.1016/0265-931X(93)90064-E.

Stoermer, E. F., and N. A. Andresen. 2006. “Atypical Tabularia in Coastal Lake Erie, USA.” In Advances in Phycological Studies. Festschrift in Honour of Prof. Dobrina TemniskovaTopalova, edited by Nadja Ognjanova-Rumenova \& Kalina Manoylov, pp. 353-363. SofiaMoscow: Pensoft Publishers \& University Publishing House.

Straub, F., and P.-Y. Jeannin. 2006. "Efficacité autoépuratoire de tracés aérien et karstique d'un effluent de station d'épuration (La Ronde, Jura suisse) : valeur indicative des diatomées.” Symbioses, nouvelle série 14: 35-41.

US EPA. 2014. US EPA National Recommended Water Quality Criteria: Aquatic Life Criteria Environmental Protection Agency Web. http://water.epa.gov/scitech/swguidance/standards/criteria/aqlife/index.cfm 
van der Kamp, G. 1995. "The hydrogeology of springs in relation to the biodiversity of spring fauna: A review.” Journal of the Kansas Entomological Society 68 (2): 4-17.

Wasser, S. P., V. V. Stupina, and P. M. Starenko. 1999. "Radioecological studies on algae.” International Journal on Algae 1 (3): 1-20. doi:10.1615/InterJAlgae.v1.i3.10.

Webster, S. C., M. E. Byrne, S. L. Lance, C. N. Love, T. G. Hinton, D. Shamovich, and J. C. Beasley. 2016. "Where the wild things are: influence of radiation on the distribution of four mammalian species within the Chernobyl Exclusion Zone.” Frontiers in Ecology and the Environment 14 (4): 185-190. doi:10.1002/fee.1227.

Werum, M. 2001. Die Kieselalgen Gesellschaften in Quellen: Abhängigkeit von Geologie und anthropogener Beeinfl ussung in Hessen (Bundesrepublik Deutschland). Hessische Landesamt für Umwelt und Geologie: Wiesbaden.

Wetzel, C. E., B. Van de Vijver, S. Blanco, and L. Ector. 2019. “On some common and new cavum-bearing Planothidium (Bacillariophyta) species from freshwater.” Fottea 19 (1): 5089. doi:10.5507/fot.2018.016.

Whittaker, R. J., K. J. Willis, and R. Field. 2001. "Scale and species richness: towards a general, hierarchical theory of species diversity.” Journal of Biogeography 28: 453-470. doi:10.1046/j.1365-2699.2001.00563.x.

Wishkerman, A., and P. B. Hamilton. 2017. "DiaCurv: a value-based curvature analysis application in diatom taxonomy.” Diatom Research 32 (3): 351-358. doi:10.1080/0269249X.2017.1368718. 


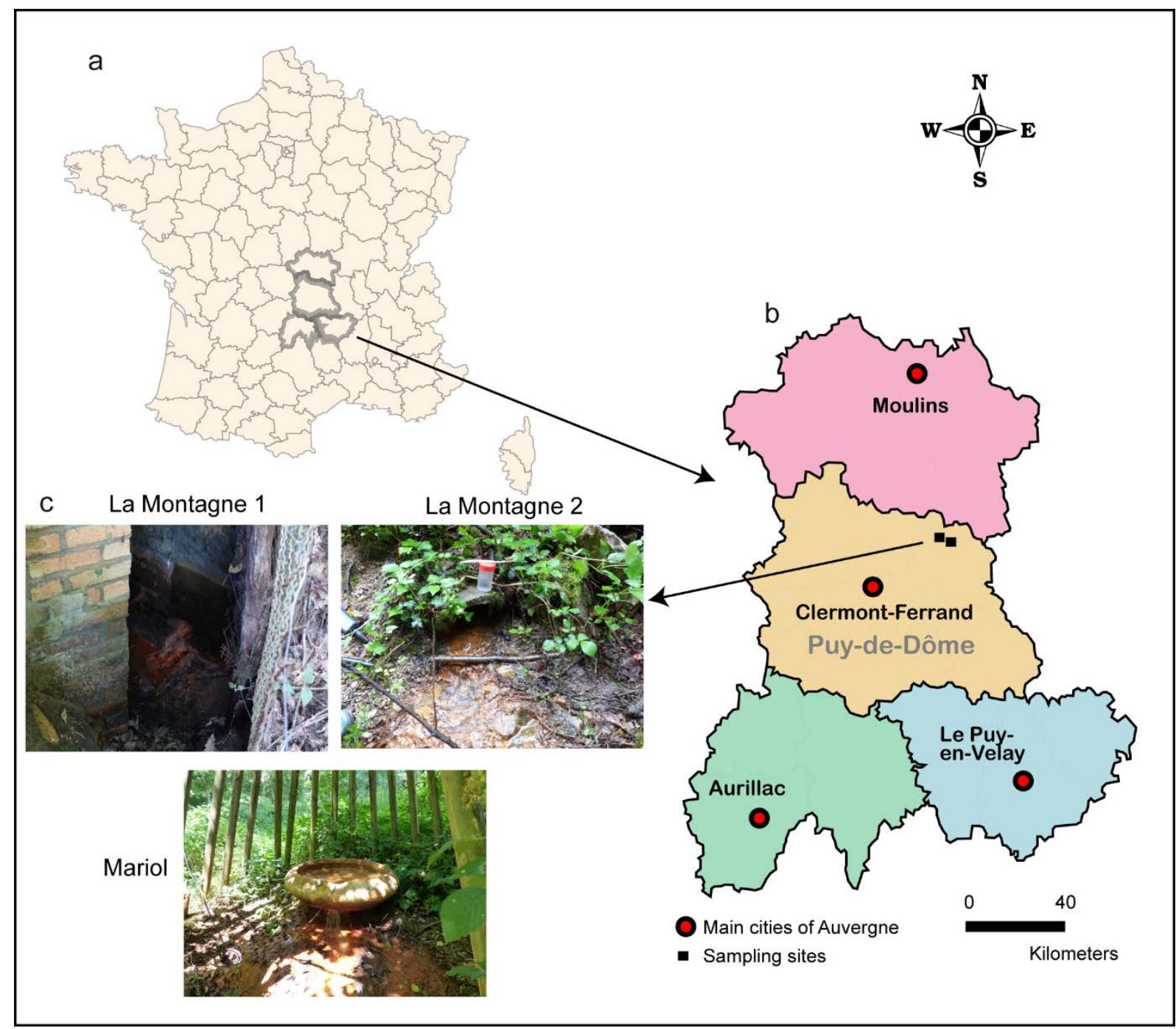

Figure 1. Studied mineral springs: general location of the study area where La Montagne and Mariol springs are situated (square) (a; b); photographs of the springs (c). 


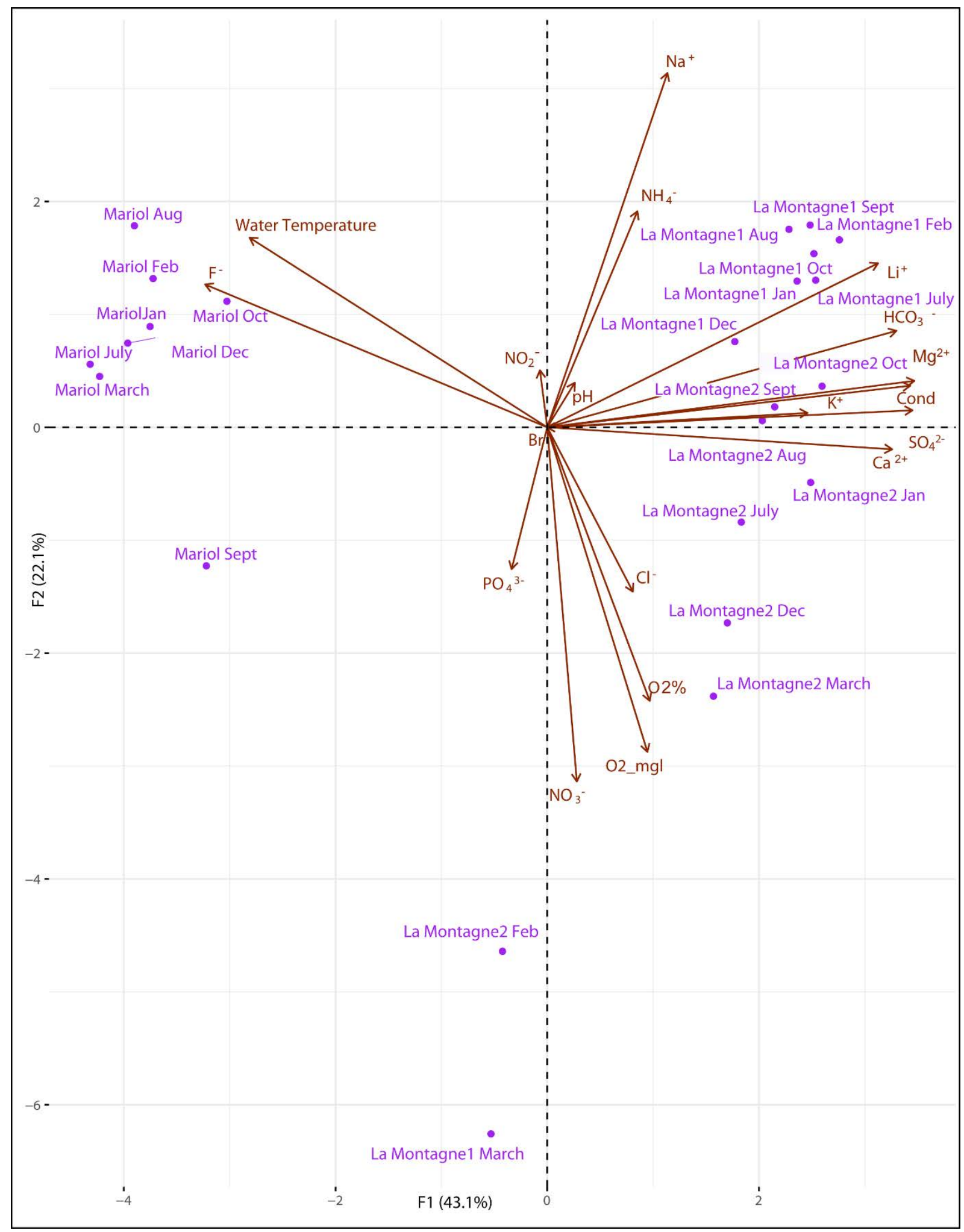

Figure 2. Principal Component Analysis ordination plot for the sites: distribution of physical and chemical variables of the three sites. 


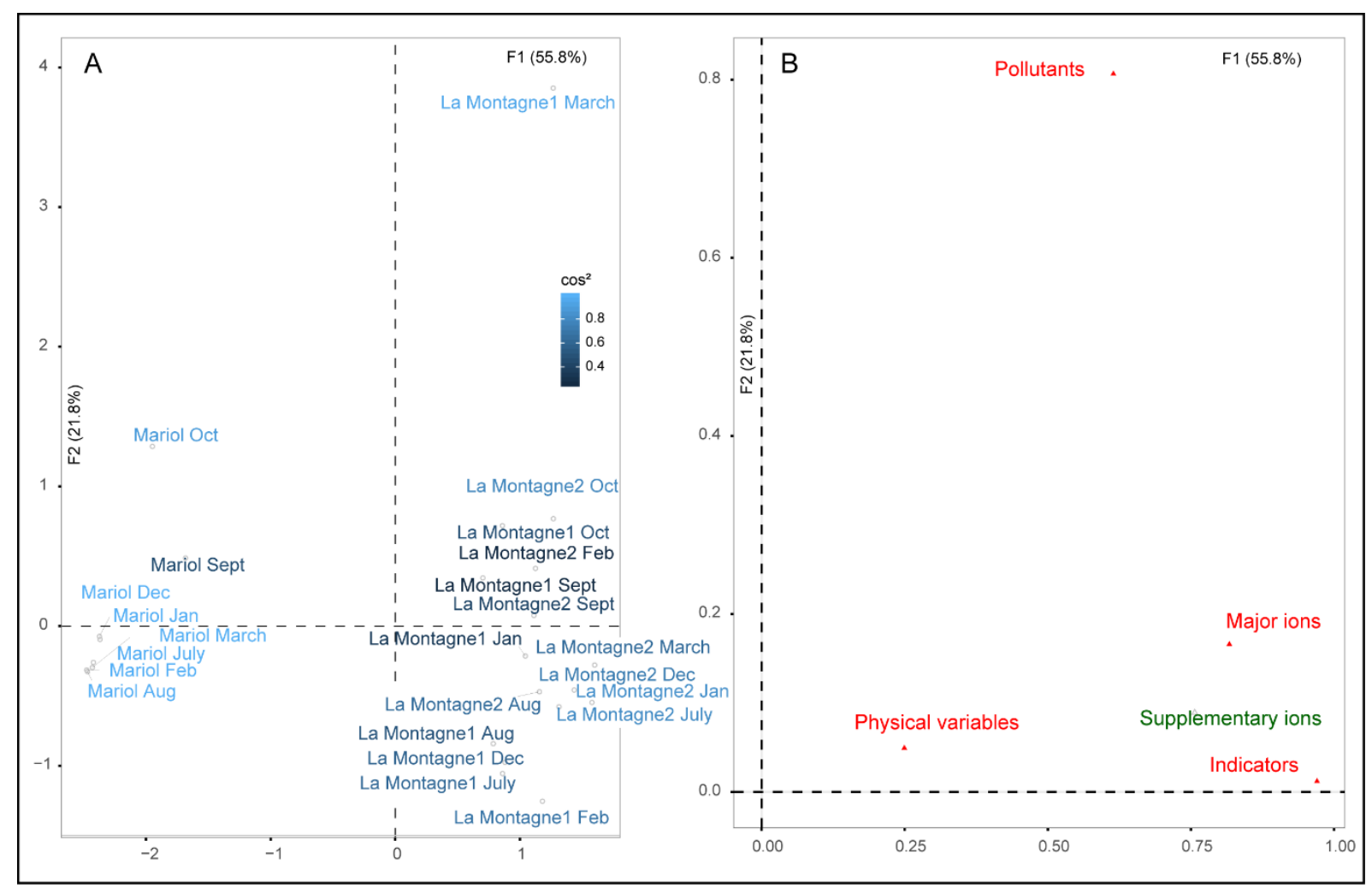

Figure 3. First factorial plan of the Multiple Factor Analysis: distribution of samples taken at La Montagne and Mariol springs (A) according to the groups (B). 


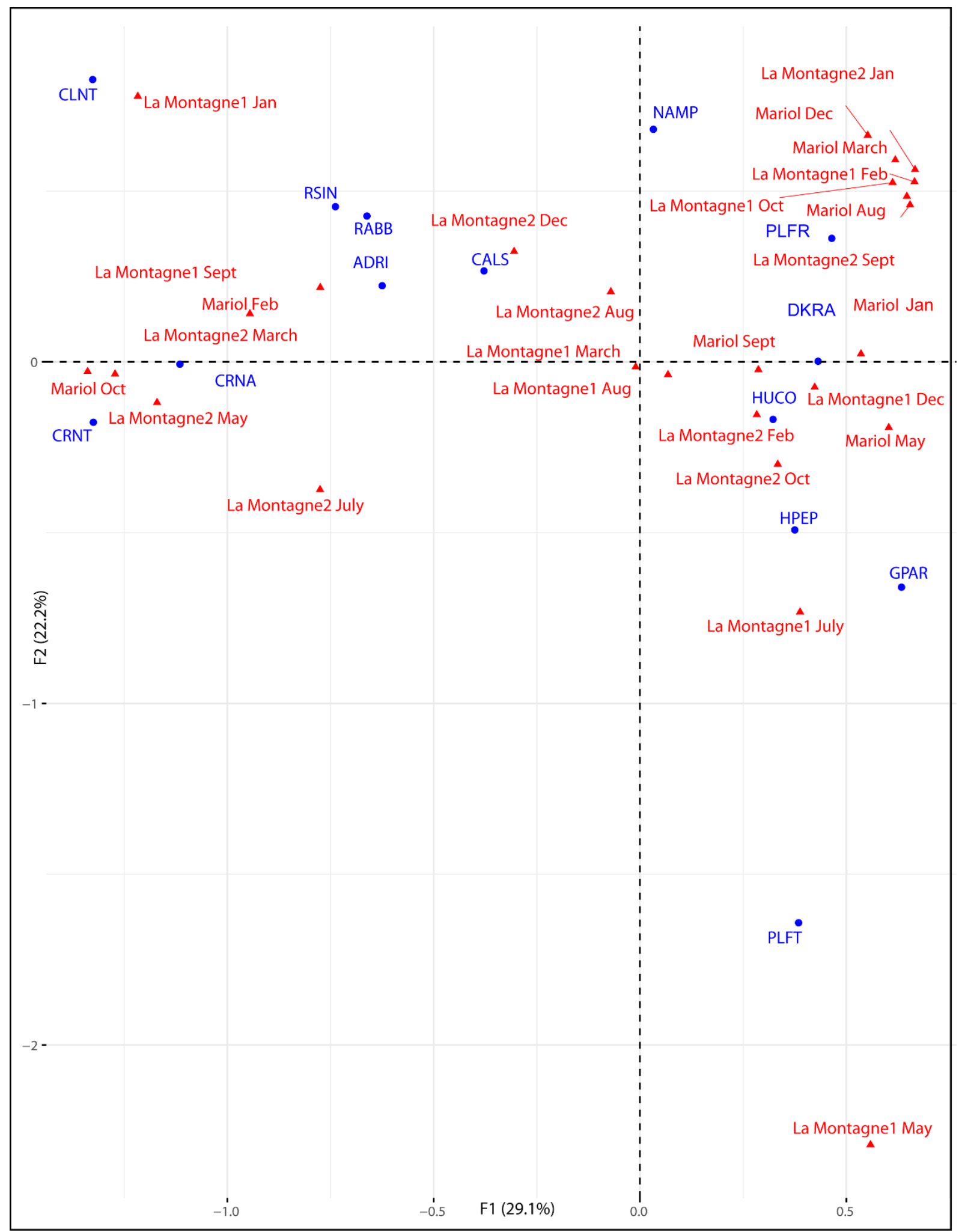

Figure 4. First factorial plan of the Factorial Correspondence Analysis done on the dominant species observed each month for each site: ADRI: Achnanthidium rivulare Potapova \& Ponader; CALS: Caloneis sp.; CLNT: Cocconeis lineata Ehrenberg; CRNA: Crenotia angustior (Grunow) Wojtal; CRNT: Crenotia angustior f. abnormal; DKRA: Diploneis krammeri Lange-Bertalot \& E.Reichardt; GPAR: Gomphonema parvulum Kützing; HPEP: Humidophila perpusilla (Grunow) R.L.Lowe, Kociolek, J.R.Johansen, Van de Vijver, Lange- 
Bertalot \& Kopalová; HUCO: Humidophila contenta (Grunow) R.L.Lowe, Kociolek, J.R.Johansen, Van de Vijver, Lange-Bertalot \& Kopalová; NAMP: Nitzschia amphibia Grunow; PLFR: Planothidium frequentissimum (Lange-Bertalot) Lange-Bertalot; PLFT: Planothidium frequentissimum (Lange-Bertalot) Lange-Bertalot f. abnormal; RABB: Rhoicosphenia abbreviata (C.Agardh) Lange-Bertalot; RSIN: Reimeria sinuata (W.Gregory) Kociolek \& Stoermer.

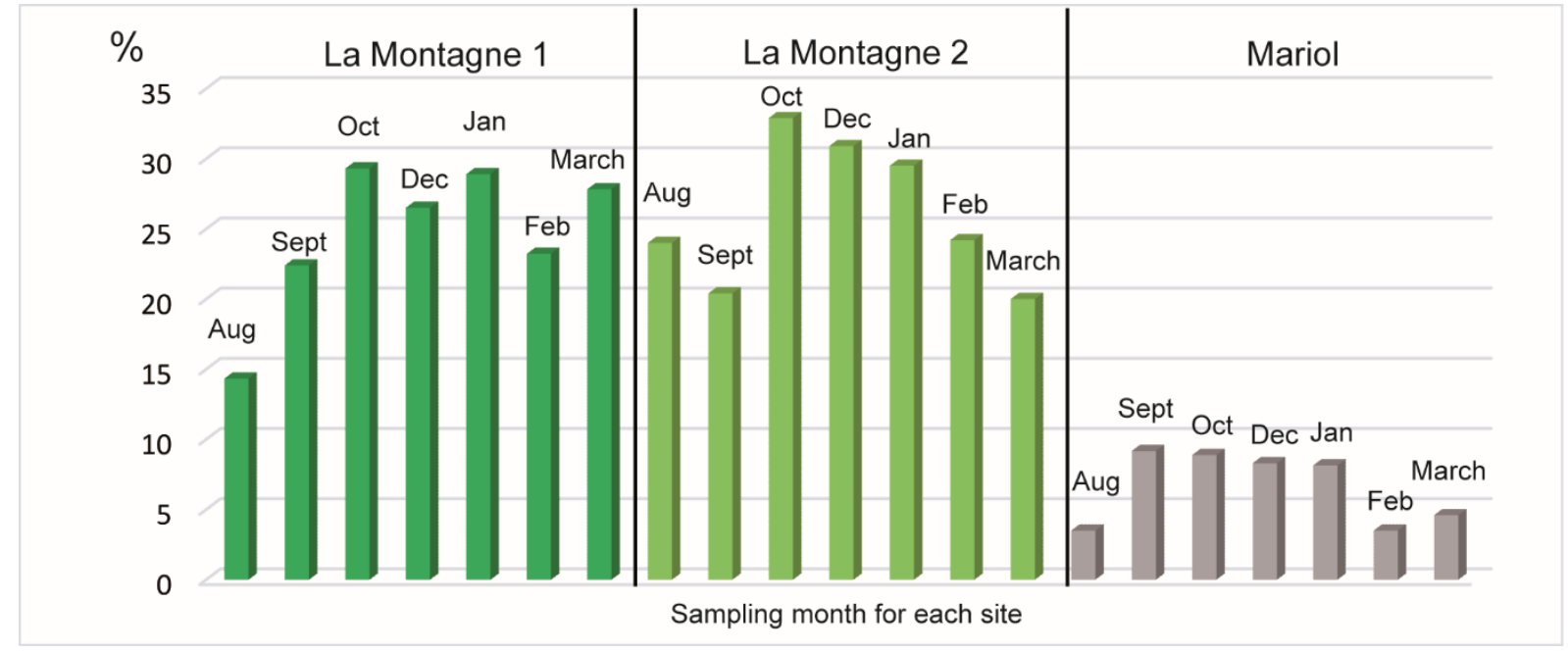

Figure 5. Percentage of deformed valves by month and spring. 


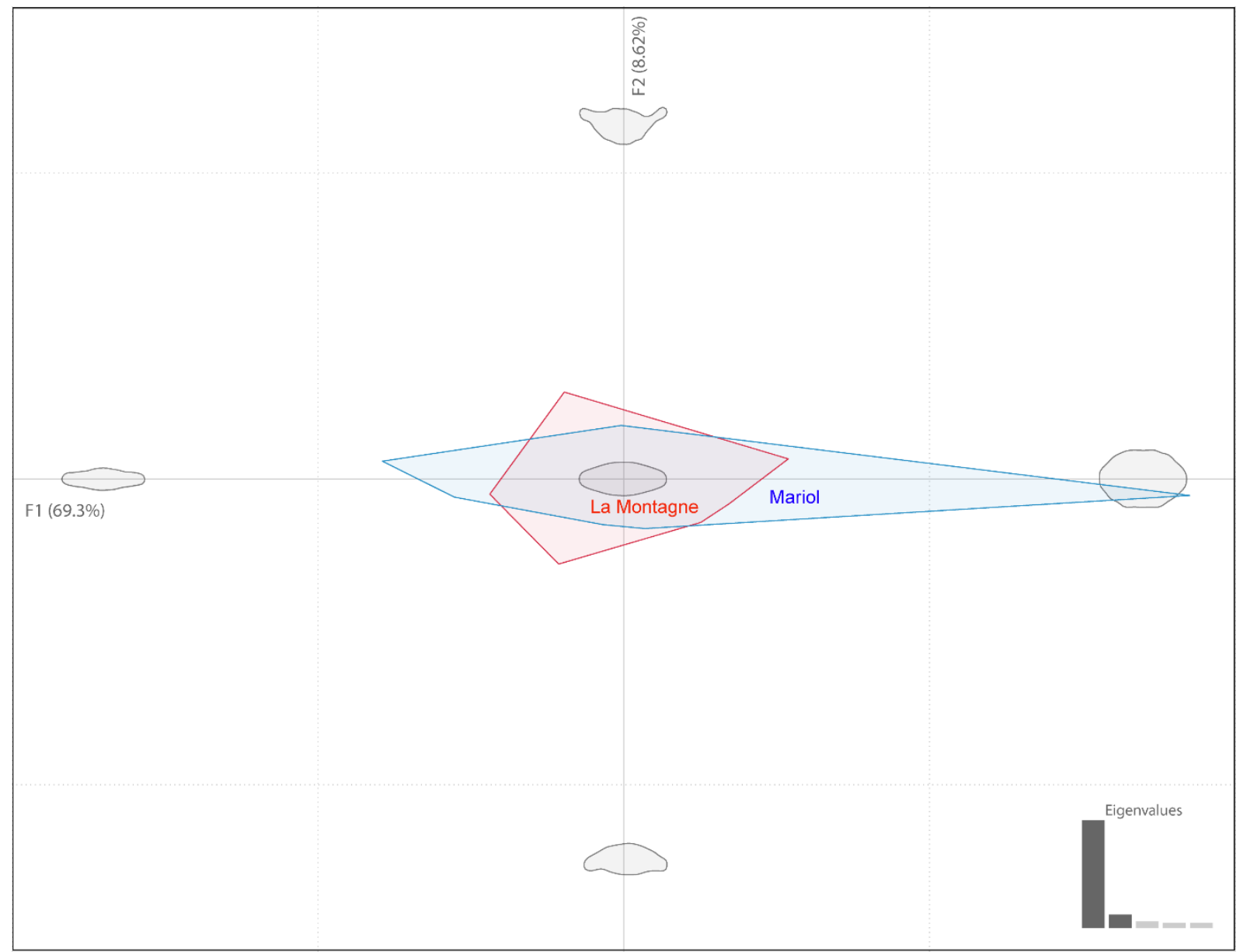

Figure 6. First factorial plan of the Principal Component Analysis done on the distribution of individuals from La Montagne and Mariol springs according to their shape. 

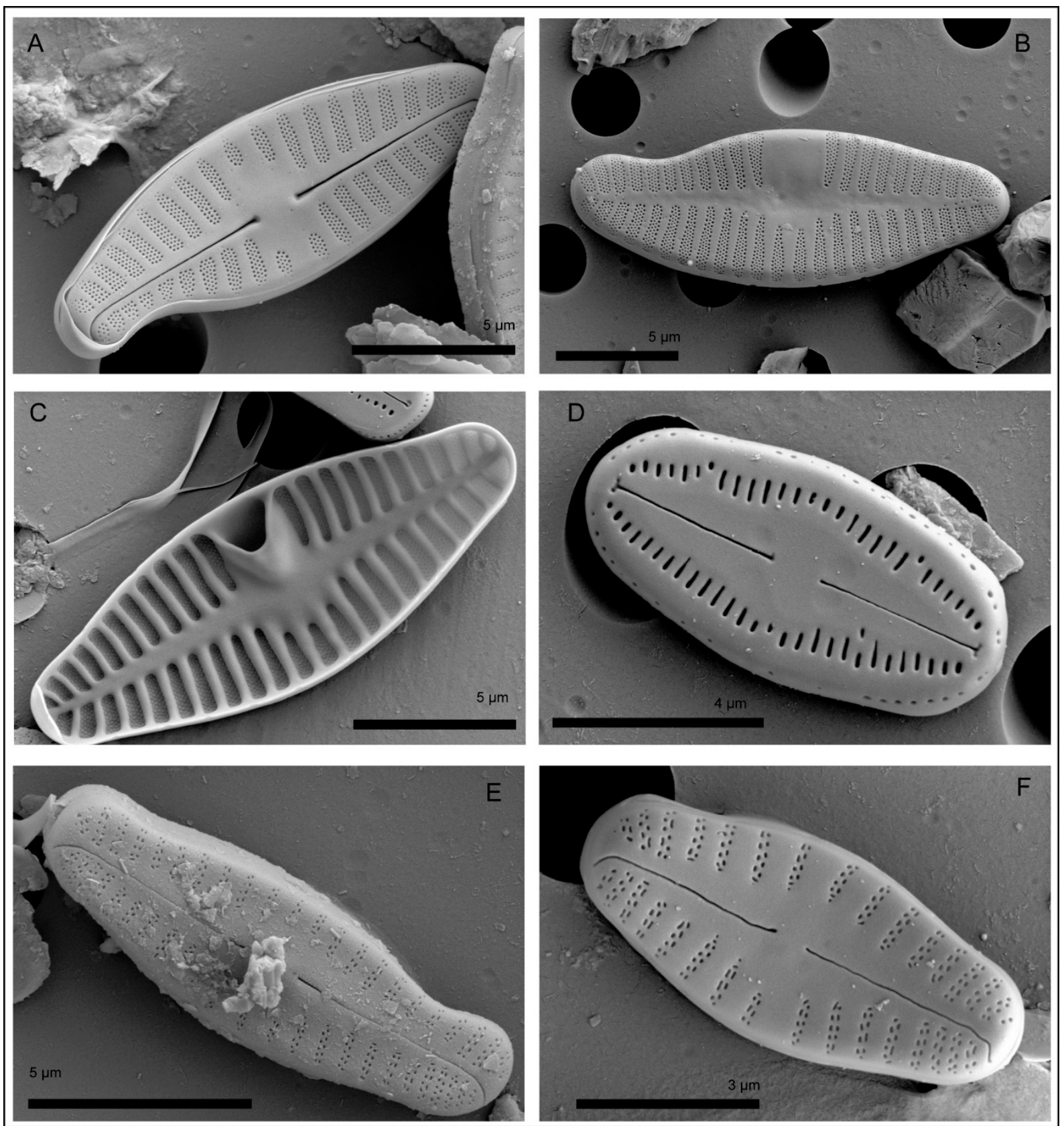

Figure 7. SEM observations of teratological valves: A, B and C: Planothidium frequentissimum; D: Humidophila perpusilla, E and F: Crenotia angustior. 


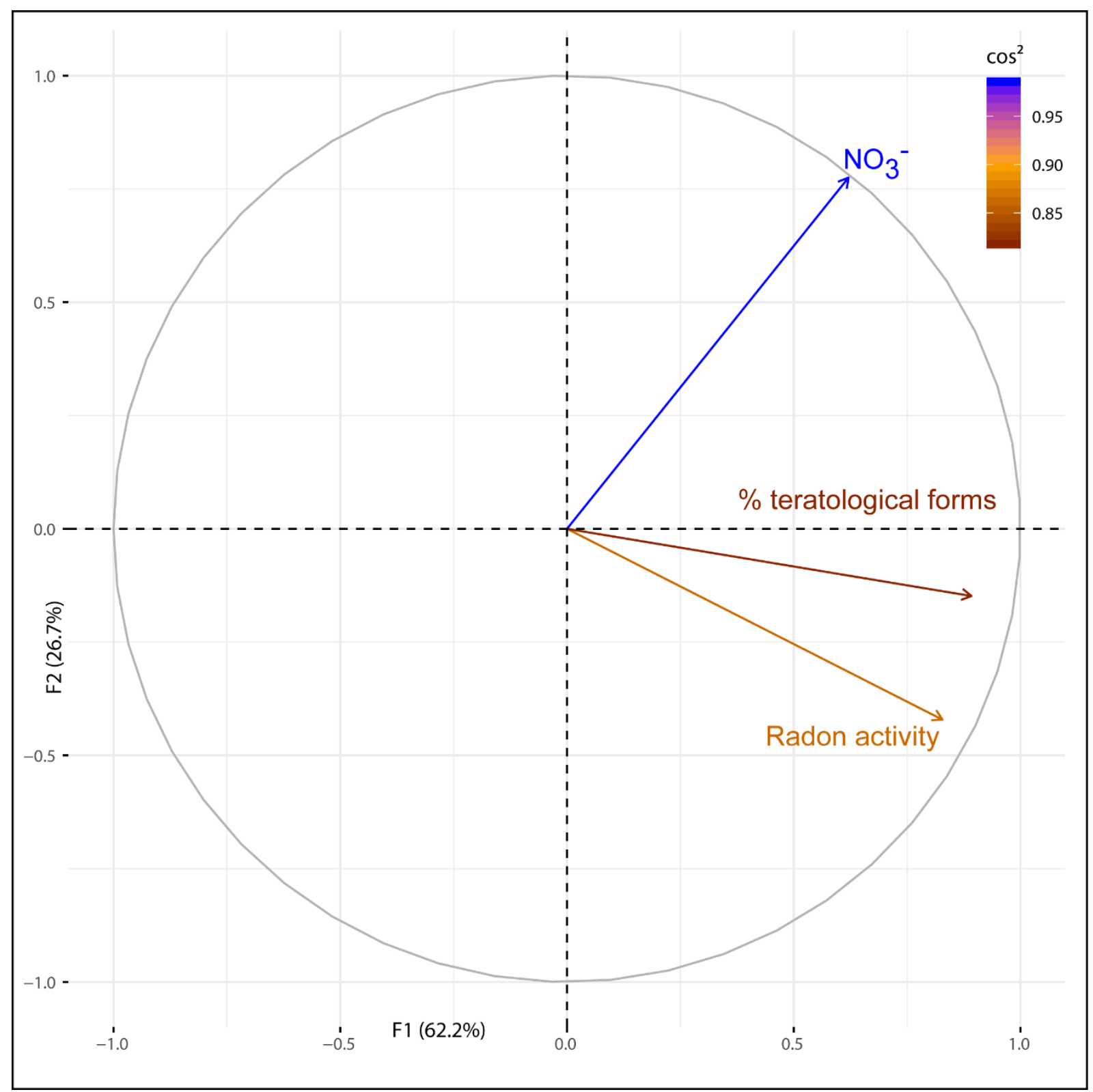

Figure 8. Correlation of the three variables (teratological valves percentage, nitrate concentration and radon activity) using Principal Component Analysis. 


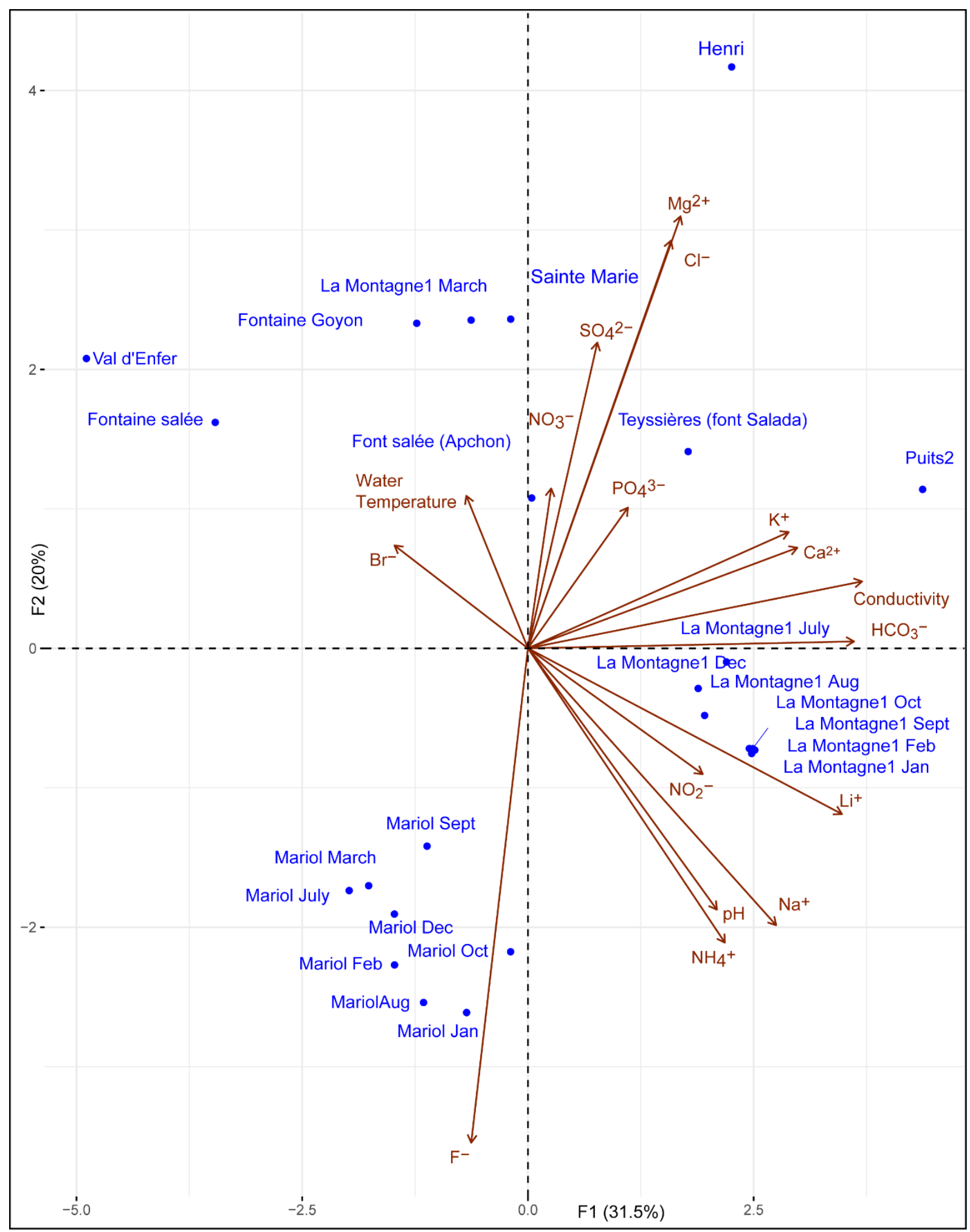

Figure 9. First factorial plan of the Principal Component Analysis done on the springs and their physical and chemical composition. 


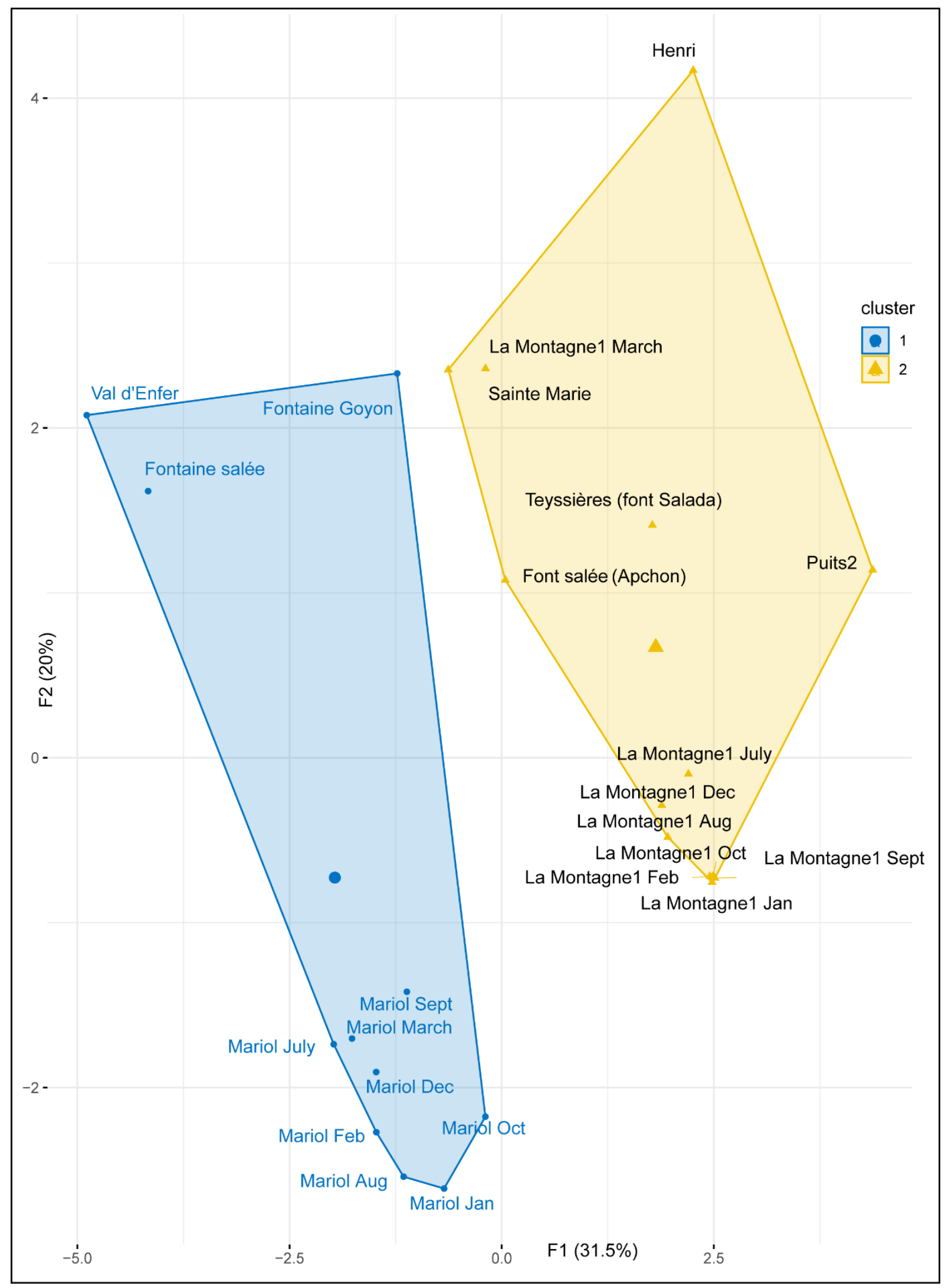

Figure 10. First factorial plan of the classification by the mobile centre method (k-means). 
Table 1. Concentration (mg L ${ }^{-1}$ ) of ions (deep rise indicators and geological nature) (mean \pm SD) for each site considering the sampling campaign (except May 2018).

\begin{tabular}{llllllll}
\hline Sites & $\mathbf{L i}^{+}$ & $\mathbf{N a}^{+}$ & $\mathbf{K}^{+}$ & $\mathbf{M g}^{2+}$ & $\mathbf{C a}^{2+}$ & $\mathbf{F}^{-}$ & $\mathbf{H C O}_{3}^{-}$ \\
\hline $\begin{array}{l}\text { La } \\
\text { Montagne 1 }\end{array}$ & $0.76 \pm 0.21$ & $142.95 \pm 37.64$ & $22.01 \pm 4.21$ & $18.16 \pm 4.85$ & $177.53 \pm 51.38$ & $1.72 \pm 0.38$ & $1011.78 \pm 295.09$ \\
La & & & & & & & \\
Montagne 2 & $0.75 \pm 0.12$ & $140.52 \pm 22.96$ & $17.22 \pm 4.10$ & $18.00 \pm 6.62$ & $182.95 \pm 33.56$ & $1.67 \pm 0.22$ & $953.222 \pm 112.36$ \\
Mariol & $0.48 \pm 0.03$ & $141.46 \pm 5.29$ & $11.67 \pm 3.56$ & $4.30 \pm 0.28$ & $32.20 \pm 4.27$ & $5.11 \pm 0.18$ & $476.111 \pm 49.49$ \\
\hline
\end{tabular}

Table 2. Concentration $\left(\mathrm{mg} \mathrm{L}^{-1}\right)$ of pollutant ions (mean $\pm \mathrm{SD}$ ) for each site.

\begin{tabular}{lllllll}
\hline Sites & $\mathbf{C l}^{-}$ & $\mathbf{N H}_{4}{ }^{+}$ & $\mathbf{N O}_{2}{ }^{-}$ & $\mathbf{N O}_{3}{ }^{-}$ & $\mathbf{P O}_{4}{ }^{3-}$ & $\mathbf{S O}_{4}{ }^{2-}$ \\
\hline $\begin{array}{l}\text { La } \\
\text { Montagne 1 }\end{array}$ & $13.09 \pm 11.46$ & $0.77 \pm 0.34$ & $0.01 \pm 0.01$ & $1.12 \pm 1.83$ & $0.05 \pm 0.01$ & $14.56 \pm 2.31$ \\
$\begin{array}{l}\text { La } \\
\text { Montagne 2 }\end{array}$ & $5.68 \pm 2.01$ & $0.76 \pm 0.25$ & $0.01 \pm 0.01$ & $1.25 \pm 1.59$ & $0.06 \pm 0.03$ & $14.77 \pm 1.43$ \\
Mariol & $4.29 \pm 3.01$ & $0.73 \pm 0.21$ & $0.01 \pm 0.01$ & $0.09 \pm 0.05$ & $0.06 \pm 0.03$ & $7.11 \pm 0.22$ \\
\hline
\end{tabular}

Table 3. Physical variables (mean \pm SD) for each site.

\begin{tabular}{|c|c|c|c|c|c|}
\hline Sites & Conductivity & pH (pH unit) & $\begin{array}{c}\text { Dissolved } \mathrm{O}_{2} \\
(\%)\end{array}$ & $\begin{array}{l}\text { Dissolved } \mathrm{O}_{2} \\
\quad\left(\mathrm{mg} \mathrm{L}^{-1}\right)\end{array}$ & $\begin{array}{c}\text { Water } \\
\text { temperature } \\
\left({ }^{\circ} \mathrm{C}\right)\end{array}$ \\
\hline \multicolumn{6}{|l|}{ La } \\
\hline Montagne 1 & $1664.33 \pm 270.95$ & $6.19 \pm 0.19$ & $5.93 \pm 10.81$ & $0.98 \pm 2.17$ & $11.02 \pm 1.36$ \\
\hline \multicolumn{6}{|l|}{ La } \\
\hline Montagne 2 & $1653.667 \pm 240.97$ & $6.53 \pm 0.23$ & $49.73 \pm 6.90$ & $5.54 \pm 0.93$ & $10.76 \pm 1.54$ \\
\hline Mariol & $848.778 \pm 81.45$ & $0.85 \pm 0.21$ & $16.54 \pm 16.10$ & $0.85 \pm 1.55$ & $16.54 \pm 1.62$ \\
\hline
\end{tabular}


Table 4: Radon activities (in $\mathrm{Bq} \mathrm{L}^{-1}$ ) measured during 9-month survey of Mariol and La Montagne springs.

\begin{tabular}{llll}
\hline Date & Site & Radon $\left(\mathrm{Bq} \mathrm{L}^{-1}\right)$ & Comment \\
\hline 1929 & La Montagne 1 & 3885 & Jacquet (1928) \\
\hline $04 / 18 / 2017$ & La Montagne 1 & $4108 \pm 1.9$ & $\begin{array}{l}\text { Previous to 9- } \\
\text { month survey } \\
\text { Previous to 9- } \\
\text { month survey }\end{array}$ \\
$05 / 30 / 2017$ & Mariol & $147 \pm 0.9$ & \\
$05 / 16 / 2018$ & La Montagne 1 & $4600 \pm 10$ & \\
$05 / 16 / 2018$ & La Montagne 2 & $1737 \pm 13$ & \\
$05 / 16 / 2018$ & Mariol & $147 \pm 2$ & \\
$01 / 18 / 2019$ & La Montagne 1 & $4561 \pm 13$ & \\
$04 / 08 / 2019$ & La Montagne 1 & $2780 \pm 10$ & \\
$04 / 08 / 2019$ & La Montagne 2 & $2100 \pm 13$ & $160 \pm 2$ \\
$04 / 08 / 2019$ & Mariol & & \\
\hline
\end{tabular}

Table 5: Mean concentrations of the physical and chemical variables related to the two groups obtained by the HAC.

\begin{tabular}{cccccccccc}
\hline & $\mathbf{F}^{-}$ & $\mathbf{N a}^{+}$ & $\mathbf{C l}^{-}$ & $\mathbf{M g}^{2+}$ & $\mathbf{K}^{+}$ & $\mathbf{L i}^{+}$ & $\mathbf{C a}^{2+}$ & $\mathbf{H C O}_{3}{ }^{-}$ & $\mathbf{C o n d u c t i v i t y ~}^{-}$ \\
\hline First Group & 3.47 & 100.35 & 6.32 & 11.79 & 12.45 & 0.349 & 39.9 & 425.91 & 772.16 \\
Second Group & 1.32 & 149.84 & 19.37 & 31.18 & 21.58 & 0.75 & 155.37 & 979.53 & 1634.69 \\
\hline
\end{tabular}

Table 6. Radon activities (in $\mathrm{Bq} \mathrm{L}^{-1}$ ) measured at the "mirror” springs.

\begin{tabular}{|c|c|c|c|c|c|}
\hline Springs & $\begin{array}{l}\text { Font salée } \\
\text { (Apchon) }\end{array}$ & $\begin{array}{l}\text { (Teyssières) } \\
\text { Font salada }\end{array}$ & Sainte-Marie & Fontaine salée & $\begin{array}{l}\text { Fontaine } \\
\text { Goyon }\end{array}$ \\
\hline Radon rates in the water & $49 \pm 1$ & $135 \pm 2$ & $121 \pm 2$ & $9 \pm 0.5$ & $7.7 \pm 0.2$ \\
\hline
\end{tabular}

Table 7. Percentage of teratological forms in “mirror” springs.

\begin{tabular}{cccccc}
\hline Springs & $\begin{array}{c}\text { Font salée } \\
\text { (Apchon) }\end{array}$ & $\begin{array}{c}\text { Teyssières } \\
\text { (Font salada) }\end{array}$ & Sainte-Marie & Fontaine salée & Fontaine Goyon \\
\hline $\begin{array}{c}\text { Rate of } \\
\text { teratological } \\
\text { shape (\%) }\end{array}$ & 6.3 & 3.1 & 6.8 & 7.5 & 10.5 \\
Dominant & $\begin{array}{c}\text { Planothidium } \\
\text { frequentissimum } \\
\text { species }\end{array}$ & $\begin{array}{c}\text { Planothidium } \\
\text { sp. (39\%); } \\
\text { Achnanthidium } \\
\text { microcephalum } \\
(21 \%)\end{array}$ & $\begin{array}{c}\text { Planothidium } \\
\text { sp. (62\%); } \\
\text { Crenotia } \\
\text { thermalis } \\
(27 \%)\end{array}$ & $\begin{array}{c}\text { Planothidium } \\
\text { frequentissimum } \\
(72 \%)\end{array}$ & $\begin{array}{c}\text { Planothidium } \\
\text { frequentissimum } \\
(97 \%)\end{array}$ \\
\hline
\end{tabular}


Table 8. Analysis of the trace elements in the water sample collected on January $18^{\text {th }} 2019$ at La Montagne spring.

\begin{tabular}{ll}
\hline Trace elements & $\mathrm{ng} \mathrm{ml}^{-1}$ \\
\hline Lithium (Li) & 1044 \\
Beryllium (Be) & 27 \\
Arsenic (As) & 64 \\
Rubidium (Rb) & 138 \\
Strontium (Sr) & 1029 \\
Yttrium (Y) & 43 \\
Cesium (Cs) & 55 \\
Barium (Ba) & 281 \\
Lead (Pb) & 52 \\
Uranium (U) & 15 \\
\hline
\end{tabular}

